\title{
Geologic constraints and speleogenesis of Cova des Pas de Vallgornera, a complex coastal cave from Mallorca Island (Western Mediterranean)
}

\author{
Joaquín Ginés $^{1 *}$, Joan J. Fornós ${ }^{2}$, Angel Ginés ${ }^{1}$, Antoni Merino ${ }^{3}$, and Francesc Gràcia ${ }^{1,4}$
}

${ }^{1}$ Federació Balear d'Espeleologia. C/ Uruguai s/n, Palma Arena. 07010 Palma de Mallorca, Illes Balears, Spain

${ }^{2}$ Departament de Ciències de la Terra. Universitat de les Illes Balears, Ctra. de Valldemossa km 7.5. 07122 Palma de Mallorca, Illes Balears, Spain ${ }^{3}$ Grup Espeleològic de Llubí, FBE, Illes Balears, Spain

${ }^{4}$ Grup Nord de Mallorca, FBE, Pollença, Illes Balears, Spain

\begin{abstract}
The flat areas of eastern and southern Mallorca host a remarkable coastal karst, where Cova des Pas de Vallgornera stands out due to its length (more than $74 \mathrm{~km}$ ) and its special morphological suite. The pattern of the cave is quite heterogeneous showing sharp differences produced by the architecture of the Upper Miocene reef: spongework mazes and collapse chambers dominate in the reef front facies, whereas joint-guided conduits are the rule in the back reef carbonates. Regarding the speleogenesis of the system, a complex situation is envisaged involving three main agents: coastal mixing dissolution, drainage of meteoric diffuse recharge, and hypogene basal recharge related to local geothermal phenomena. The cave system is disposed in two main tiers of passages, of which geomorphologic interpretations are derived from their elevation data. The evolutionary trends as well as the chronology of the different cave sections are difficult to establish owing to the frequent shifting of the coastal base level during the Plio-Quaternary. In this respect, the genesis and evolution of the cave were fully controlled by sea-level fluctuations in the Western Mediterranean basin, with the main phases of cave formation, based on vertebrate paleontological data, going back to mid-Pliocene times.
\end{abstract}

Keywords: coastal karst; southern Mallorca; lithologic variability; cave patterns; speleogenesis

Received 7 October 2013; Revised 24 October 2013; Accepted 18 February 2014

Citation: Ginés J., Fornós J.J., Ginés A., Merino A. and Gràcia F., 2014. Geologic constraints and speleogenesis of Cova des Pas de Vallgornera, a complex coastal cave from Mallorca Island (Western Mediterranean). International Journal of Speleology, 43 (2) 105-124. Tampa, FL (USA) ISSN 0392-6672 http://dx.doi.org/10.5038/1827-806X.43.2.2

\section{INTRODUCTION}

Coastal karst is a research field of growing interest as evidenced by the recently edited book by Lace \& Mylroie (2013) as well as by specific scientific meetings like the Island Karst Symposium, coordinated by J.E. Mylroie and A. Ginés and held in 2009 at Kerrville (Texas) during the $15^{\text {th }}$ International Congress of Speleology. Going back to the last decades of the past century, the late J.N. Jennings (1985) devoted a whole chapter of his fundamental book to Coast and Karst just when the geochemical and geomorphologic implications of the littoral mixing zones were put forward (Plummer, 1975; Back et al., 1984); subsequently, a new paradigm about speleogenesis in coastal settings was formulated through the flank margin cave model (Mylroie \& Carew, 1990) defining a new cave type fully specific to the carbonate islands.
The flank margin model of cave evolution, based on the well-known examples from the Bahamas archipelago, was later complemented and enlarged in the form of the CIKM (Carbonate Island Karst Model) which was an important attempt taking into account the great diversity of geological settings present in limestone islands (Mylroie \& Carew, 2000). This initial theoretical approach has been repeatedly improved on the basis of world-wide island locations, leading to updates of the CIKM as shown in Jenson et al. (2006) and Mylroie \& Mylroie (2007); nevertheless, the complexity of situations observed in the littoral karst areas all over the world is far enough larger than those reflected in these last versions of CIKM. Regarding this fact, several recent papers deal with extensive cave forming processes that don't strictly fit within the flank margin model of cave evolution or the CIKM, 
for example those occurring in continental settings as Florida, USA (Florea et al., 2007; Gulley et al., 2013) or the Yucatan Peninsula, Mexico (Beddows, 2004; Smart et al., 2006; Kambesis \& Coke, 2013).

Since the middle of the $19^{\text {th }}$ century until today, a significant number of coastal caves have been reported and studied in the the Upper Miocene eogenetic carbonate rocks of southern Mallorca (Ginés \& Ginés, 2007; Ginés et al., 2013). The explorations performed during the last decade in Cova des Pas de Vallgornera (Llucmajor municipality) have lead to the discovery of important extensions (Merino et al., 2011b), today totalizing over $74 \mathrm{~km}$ of development. Nowadays it is the most important endokarst phenomenon in the Balearic archipelago, being undoubtedly one of the more remarkable littoral caves in the Western Mediterranean basin. The cave certainly stands out regarding its unusual morphological suite, and provides an excellent illustration on how lithology influences the pattern and morphology of the cave (Ginés et al., 2009a). These geologic and morphogenetic aspects will be dealt with thoroughly in the present paper, according to the current knowledge about karstification in coastal environments. The main proposed goal is to elucidate the complex speleogenetic mechanisms leading to the formation of this special littoral cave, which until now have only been hinted in previous publications (Ginés et al., 2009b; Fornós et al., 2010a).

\section{GEOLOGIC AND GEOGRAPHIC SETTING}

The island of Mallorca is located in the middle of the complex geological frame of the Western Mediterranean Sea, being the largest (near 3,667 $\mathrm{km}^{2}$ ) and the most central island of the Balearic archipelago. Generally speaking, these islands are characterized by folded and thrusted Mesozoic, Paleogene and Middle Miocene rocks that are flanked by down-dropped areas covered with only slightly deformed Upper Miocene to Pleistocene sedimentary rocks.

From a physiographical point of view the archipelago is the eastern emergent part of the so-called Balearic Promontory: the north-eastward extension of the Betic Range External Zone, a thickened continental crustal unit forming the NE continuation of the Alpine Betic thrust and fold belt, built during the Middle Miocene (Gelabert et al., 1992).

The stratigraphic sequence that crops out in Mallorca is continuous, practically without interruption, from the Carboniferous to the present-day (Fornós et al., 2002). The carbonate lithologies, occurring almost continuously since the Middle Triassic to the present (Fornós \& Gelabert, 1995), are the scene of a remarkable wide range of exo- and endokarstic morphologies.

The island's sedimentary deposits experienced extension and thinning during Mesozoic times. Subsequently, they were affected during the Cenozoic by two tectonic phases that shaped the present physiography of Mallorca. The first one was a compression and thrusting phase lasting from the Paleogene to the Middle Miocene. The second phase was an extensive one that took place during the Upper Miocene. This extension phase has generated a structure characterized by horsts and grabens, which are not older than Langhian (Middle Miocene) and are bounded by Upper Miocene normal faults (Gelabert et al., 1992).

The horsts originated two more or less parallel mountain ranges, orientated NE-SW (Serra de Tramuntana and Serres de Llevant), along with a series of small hills located in between (Serres Centrals) (Fig. 1). The grabens developed on the foreland of these ranges are filled with sediments of Middle Miocene to Quaternary age, that are unaffected by tectonics. The differentiation between ranges and plains is not always so clear; occasionally their limits are angular discordances, where structures produced during the Mesozoic (normal faults) or in the Lower Cenozoic (mainly thrusts) are buried by Tertiary and Quaternary deposits (Gelabert et al., 1992).

It is important for the purpose of this work to note that, resulting from the mid-Miocene major compressional events, a number of paleo-islands remained individualized (the horsts). The islands were covered by an epicontinental sea that favored the development of a coral reef environment around the uplifted areas. Upper Miocene carbonate platforms grew in shallow submerged areas around all Balearic paleo-islands, but most extensively on their southern margins (Pomar, 1991). Specifically, in the southern margin of Mallorca (the Llucmajor Platform) a thick slab of carbonate deposits built up, creating a structural post-orogenic platform that stretches around the central and eastern folded ranges (Fig. 1). These deposits include a Late Tortonian-Early Messinian Reef Complex (Pomar et al., 1996), where most of the littoral caves in the island occur.

At the end of the Miocene, during the Messinian, the Mediterranean experienced an extreme recession, which left the Balearics completely exposed. Following the Lower Pliocene transgression, sea level covered the lowland areas of Mallorca (the Neogene basins), whereas the folded areas (ranges) remained emerged. Finally, the Pleistocene glacial cycles led to sea-level rises interspersed with important regressions that are well-recorded along the coasts of the island (Butzer and Cuerda, 1962; Ginés et al., 2012).

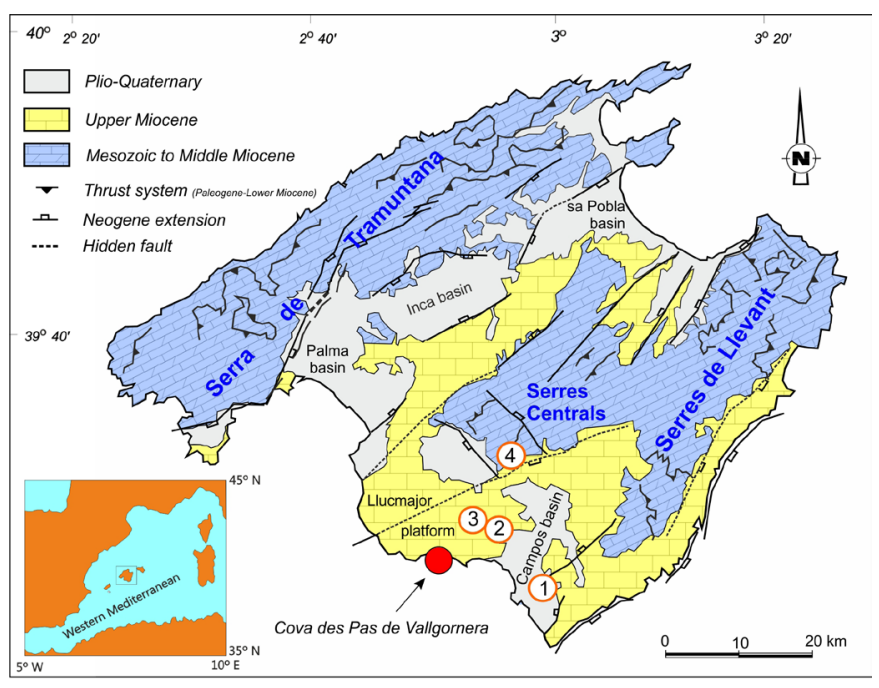

Fig. 1. Simplified geologic map of Mallorca Island indicating the main physiographical units and the karst locations mentioned in the text. 1) Font Santa de Sant Joan; 2) Pou de Can Carro; 3) Cova de sa Guitarreta; 4) Cova Nova de Son Lluís. 


\section{Additional geographic data}

As a general geomorphologic overview (Fig. 2), the southern part of the Llucmajor Platform corresponds to a gently domed structure of Upper Miocene sedimentary rocks forming a rather tabular relief, which corresponds, as has been said, to the southward progradation of a reefal unit over the preorogenic basement. Some authors (Pomar $\&$ Ward, 1994) have suggested the presence of a strike-slip fault (SW-NE) with a hectometric dextral displacement; nevertheless, it seems more probable that the gently domed appearance corresponds to a SW-NE antiform structure created by a series of listric normal faults (Gelabert, 1998; Fornós et al., 2002). The area where the cave is located has a gentle slope in a southeast direction coincident with the meridional anticlinal flank (Fig. 2).

A poorly developed fluvial system is incised over the carbonate platform, consisting nowadays in dry valleys with only ephemeral discharge after heavy precipitation; the most important of these creeks is Torrent de Garonda, located to the northeast of the cave area. The fluvial network is tightly controlled by relevant fractures and related joints (Fig. 2), that are evident as well in the outline of some coastal cliffs. The surficial drainage system becomes more deeply incised when approaching the coastline, and therefore calas are formed. These macroforms are characteristic coastal embayments (Gómez-Pujol et al., 2013) related to steep-sided dry valleys that were deeply incised on carbonate plateaus during low sea stands; subsequently, they became drowned after the post-glacial sea level rise.
Vertical shoreline cliffs higher than $25 \mathrm{~m}$ are dominant in the Vallgornera site (Fig. 3), and are only interrupted by the already described indentations (calas), which are intercalated within a less articulated coast. Apart from the littoral cliffs, the gentle slope trend of the Vallgornera area is interrupted by a clear change in slope that approximately follows the 25-30 m contour lines (Fig. 2); this altimetric irregularity corresponds to a rather steep

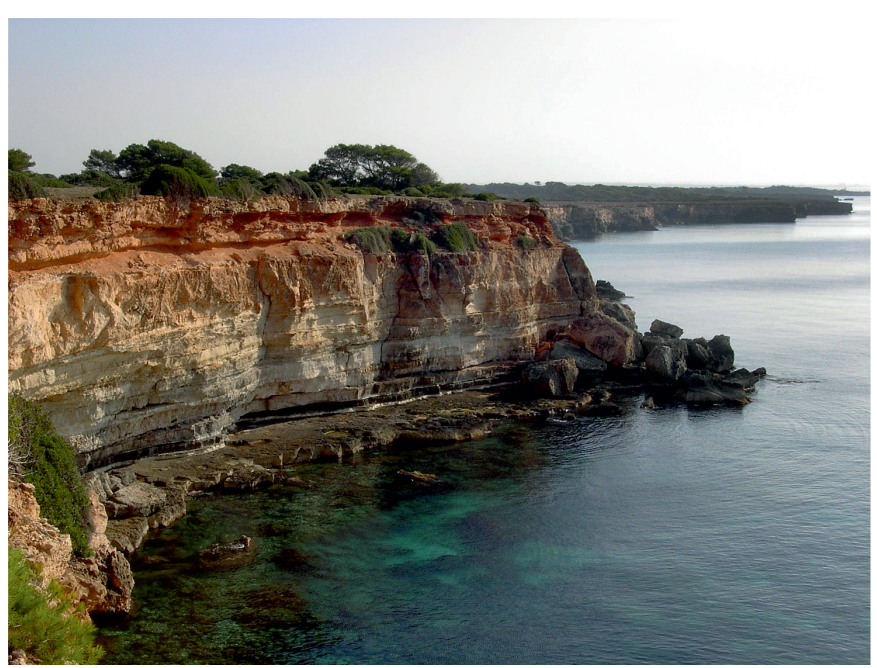

Fig. 3. Coastal cliffs in the vicinity of Cova des Pas de Vallgornera; the picture was taken in a SE direction towards S'Estalella and the subsidence basin of Campos at the farthest rear. The wave-cut erosive platform corresponds to the Upper Miocene Reef Complex, overlain by a complete sequence including from the Messinian Terminal Complex (greyish beds at the cliff base) to the Pliocene and Pleistocene reddish deposits on top.

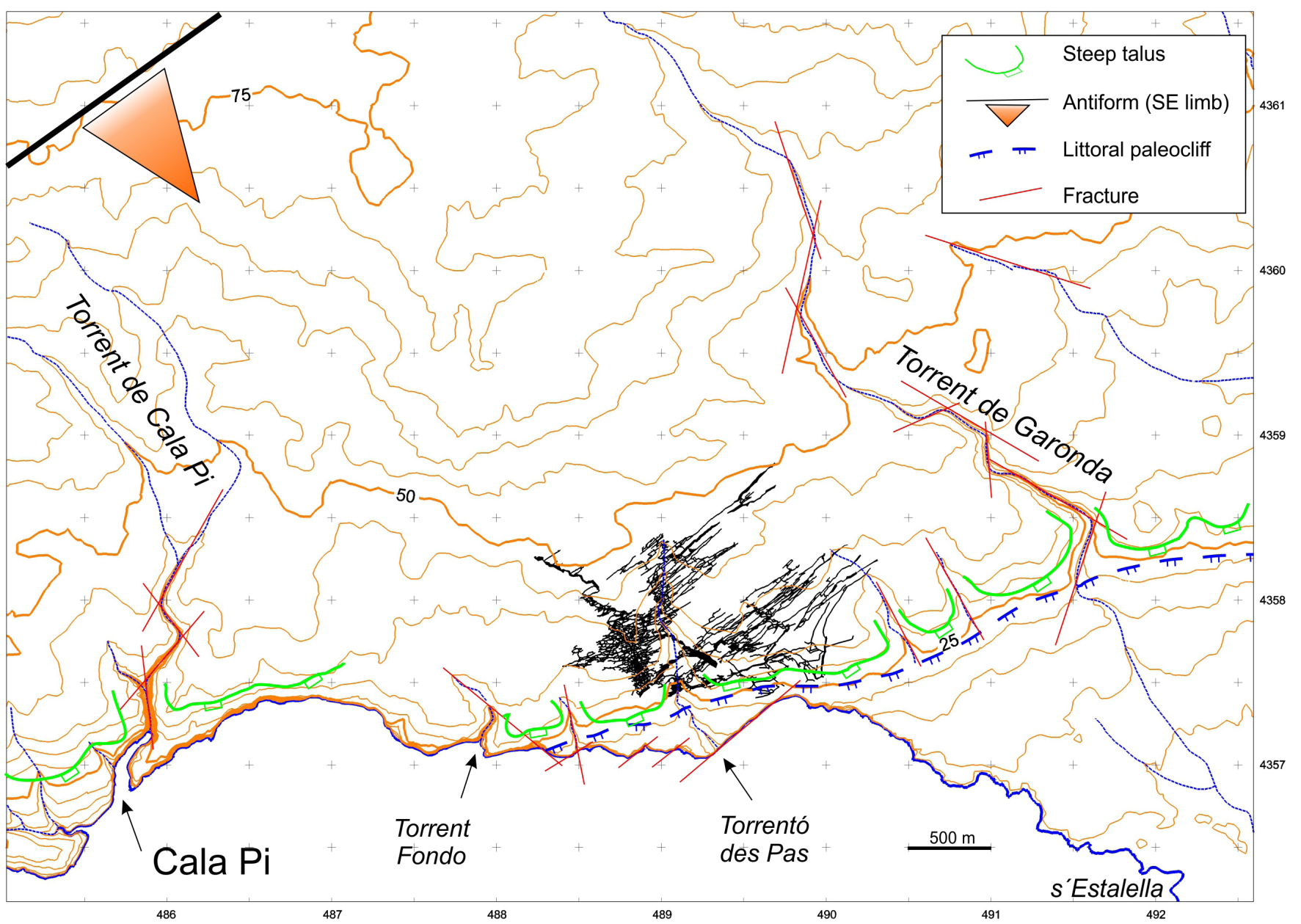

Fig. 2. Topographic and geomorphologic map of the Vallgornera area, in southern Mallorca. Contour-line interval is $5 \mathrm{~m}$. 
talus associated with the presence of a Messinian coastal paleocliff, as discussed later in the paper.

Regarding the climate, Mallorca enjoys the typical Mediterranean climate characterized by its hot and dry summers, whereas winters are mild and relatively wet. The mean annual temperature in the area is $17^{\circ} \mathrm{C}$, with mean winter and summer values of $10^{\circ} \mathrm{C}$ and $25^{\circ} \mathrm{C}$, respectively. Mean annual precipitation is less than $400 \mathrm{~mm}$ in the southern part of the Llucmajor Platform, with most rain occurring in the autumn (Guijarro, 1995). The landscape supports typical Mediterranean vegetation where bushes are dominant but interspersed with rainfed-cultivated areas existing in these arid lowlands.

The dominant main winds come from the north and west and sea breezes are very common during summer time. The wave regime over the coastal areas is characterized by a mean significant wave height greater than $1 \mathrm{~m}$ during autumn-winter months and $0.3 \mathrm{~m}$ approx. during the spring-summer seasons (Cañellas et al., 2007). The tidal range is almost negligible (the spring tidal range not exceeding $0.25 \mathrm{~m}$ ), although changes in atmospheric pressure and wind stress can account for considerable fluctuations in sea water levels (GómezPujol et al., 2007), but with a maximum fluctuation range less than $1 \mathrm{~m}$.

\section{LITHOSTRATIGRAPHY OF THE LLUCMAJOR PLATFORM}

In broad terms, the post-orogenic platform developed along the eastern and southern coasts of Mallorca is formed in an Upper Miocene to Quaternary sequence, synthetically represented in Fig. 4. The Upper Miocene carbonates consist of three sedimentary units: the Heterostegina calcisiltites at the base, considered to be Lower Tortonian (not outcropping in the studied area); the middle unit or Reef Complex that is Upper TortonianLower Messinian in age (Pomar et al., 1996); and the upper unit or Terminal Complex which is assigned to the Messinian, and is tentatively considered to be a thirdorder depositional sequence (Pomar \& Ward, 1994). Pliocene and Pleistocene deposits include beach-rock, eolianites, and paleosols.

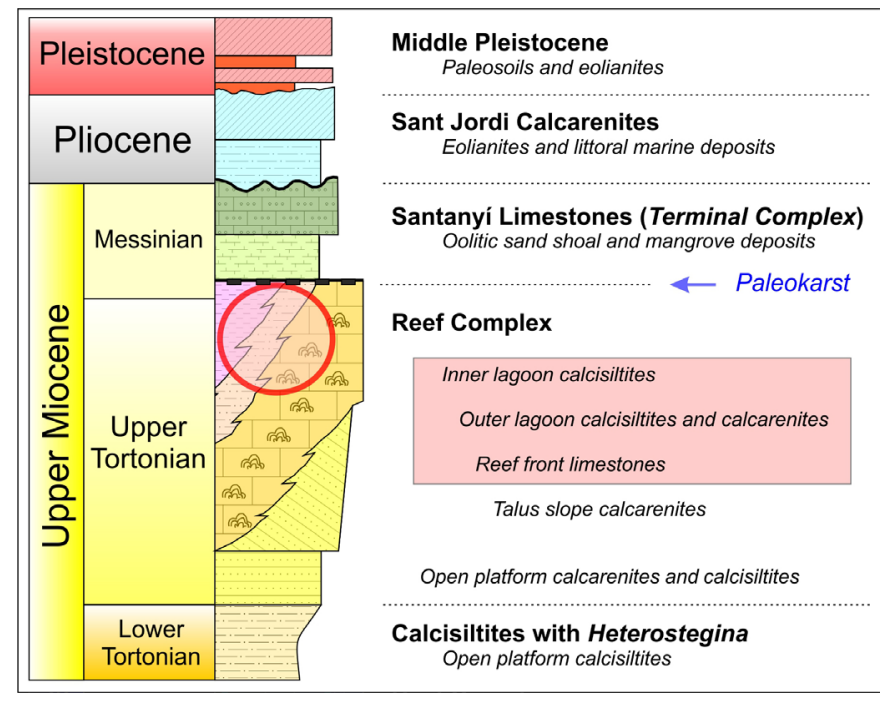

Fig. 4. Synthetic lithostratigraphic column of the Neogene in the Vallgornera area. The red circle and the pink-colored inset indicate the lithofacies where the cave is developed.
In more detail, the sea cliffs close to Cova des Pas de Vallgornera display a set of lithostratigraphic sequences, which are quite variable according to its W-E location along the shoreline (Fig. 5). A detailed lithological description of the different units is necessary in order to interpret the morphologies and pattern of the cave system as well as its evolution.

At the base of the studied sequences, the Upper Miocene limestones belonging to the Reef Complex (Pomar, 1991) crop out all along the littoral cliff (Fig. 5). These deposits vary in thickness along the coastline due to the intra and post Messinian erosive periods that had affected them; inland, they represent the unique unit where the cave system develops. This unit consists in a series of progradational (towards the SW) reef-rimmed platforms that present different facies associations, characterized in this area by welldifferentiated reef front and back reef deposits. Their architecture shows complex accretional geometric relationships related to the high-frequency oscillations in relative sea level (Pomar, 1991). The lithofacies that compose this carbonate Reef Complex -defined mainly on the basis of lithology, texture and constituentsplays an important role in the development of the cave morphology (see below). In that sense, three main types of lithofacies can be described (Fig. 4) according to Pomar et al. (1996). The reef core or reef front has a classical framestone texture due to the growth of the coral colonies (almost exclusively Porites sp.); these rock deposits have a massive appearance. Intermixed with the coral colonies there are abundant bioclastic sediments composed mainly by mollusks, bryozoans and red algae. The elevated primary porosity, which favors rudstone and grainstone textures, brings to these lithofacies a great permeability. Landward (towards the NE), these lithofacies interfinger with flatlying lagoon deposits composed of partly dolomitized packstone, grainstone and, especially, wackestone textures. The outer lagoon is dominated by the coarsest facies and includes the sporadic presence of poorly developed patch reefs. The sediments are mainly composed of foraminifers, equinoids and red algae fragments. Farther inland the lagoon sediments become mudstones to wackestones (the inner lagoon) with peloidal sands that include abundant foraminifers and whole mollusks. The sediments, which are slightly dolomitized, show a conspicuous thin horizontal lamination. The muddy texture of this lithofacies gives these deposits a very low permeability.

An important erosion and karstification surface over the Reef Complex was followed by a transgressive sequence known as the Terminal Complex (Esteban, 1979) later defined by Fornós and Pomar (1984) as the Santanyi Limestones (Fig. 4). They correspond to a series of more or less restricted coastal environments and oolitic sand shoals with stromatolites (Pomar et al., 1996). In this area, it reaches a maximum thickness of around $10 \mathrm{~m}$ and consists of two main units. The marly lower one has a very pronounced stratification due to the alternation of miliolid packstones and grainstones, with vertical root traces and abundant accumulations of Ostraea sp. (mangrove swamps) that usually end in thin laminated criptalgal boundstones and mudstones 

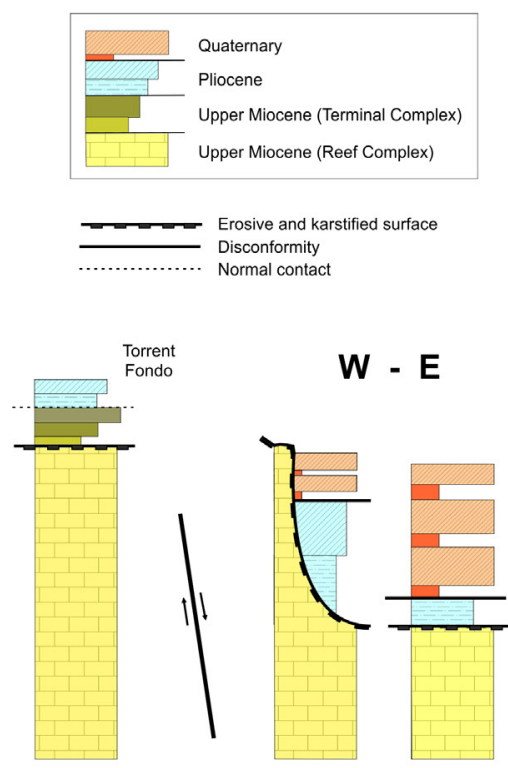

(1)
(2)

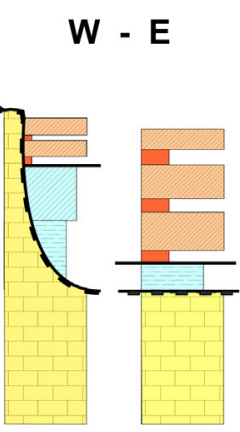

(3)

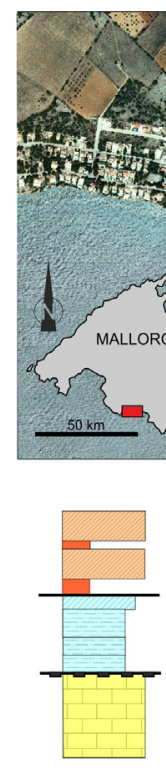

(4)
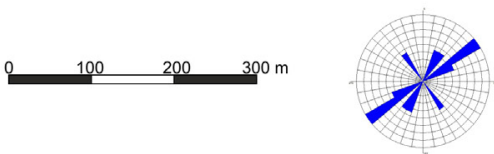

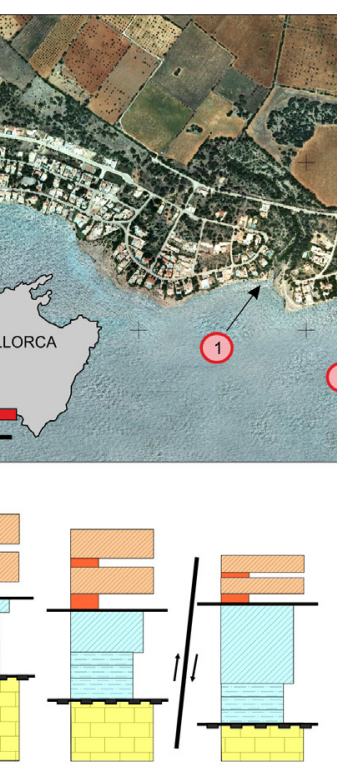

(5)

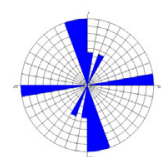

(6)

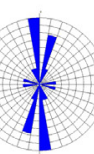

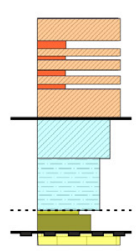

(7)

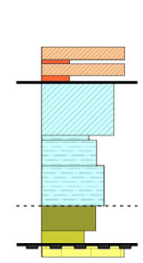

(8)

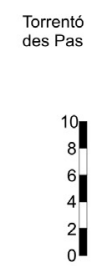

10
8
4
4
01
0

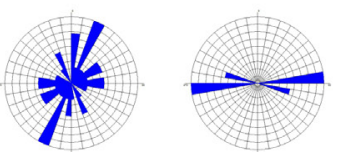

Fig. 5. Lithostratigraphic columns obtained along the sea cliffs of the Vallgornera area with the representation of main joint and fracture orientations.

(intertidal). The upper unit, which is quite massive, is formed by cross-bedded oolitic grainstones that include giant stromatolites (oolitic sand shoal) and abundant skeletal grainstones and stromatolites (subtidal). The Terminal Complex outcrops in the easternmost coastal cliffs of the study area, with a thickness around $10 \mathrm{~m}$ (Fig. 5, column 9). Westward, these levels quickly decrease in thickness (columns 7-8), disappearing due to the erosive late Messinian low-stand and subsequent Pliocene transgression (columns 2 to 6). At the mouth of the small creek named Torrent Fondo (Fig. 5, column 1) the Terminal Complex reappears, but at an elevation over $20 \mathrm{~m}$ a.s.1. due to Plio-Quaternary tectonics.

Overlying the major Messinian erosion surface, a Pliocene regressive sequence fills the remaining reefrimmed basins above the Upper Miocene sequence (Pomar, 1991). Never more than $10 \mathrm{~m}$ thick in this area (Figs. 5 and 6), and increasing to the southeast towards the basin depocenter, these deposits represent the westernmost margin of sedimentation in the Campos basin (see location in Fig. 1) during the Pliocene transgression (Colom, 1985). This regressive sequence has two main units that correspond to a coastal and shallow restricted marine environment at the base that evolves to an eolian deposition. The basal contact of the lower unit contains transgressive lag deposits composed of calcarenites with abundant mollusk macrofauna deposited on a soft, burrowed surface. These calcarenitic shoreface deposits, including an alternance of rudstones and floatstones with large bivalves and many trace fossils, have horizontal laminated bedding sometimes with slightly eroded layers. This evolves to a more hydrodynamic sequence with conspicuous medium-sized crossbedded structures. Abundant low angle crossbedding and wave ripples with abundant trace fossils characterize the foreshore environment. Gradually, the backshore gives way to eolian sedimentation. Grainstones composed of medium-sized bioclastic sand display the typical eolian cross-bedding.

On top, a Middle Pleistocene eolian system (Nielsen et al., 2004) unconformably overlies both the Upper Miocene limestones and/or the Pliocene deposits (Fig. 3). It consists of a succession of interbedded greyish red eolian carbonates and darker red colluvial deposits up to $10 \mathrm{~m}$ thick (Figs. 5 and 6). The eolian sediments form part of an extensively eolian system that extended more than $15 \mathrm{~km}$ inland, covering today a large part of the Llucmajor Platform. It decreases in thickness towards the southeast agreeing with the data obtained from the cross-bedding that indicate sand transport towards the

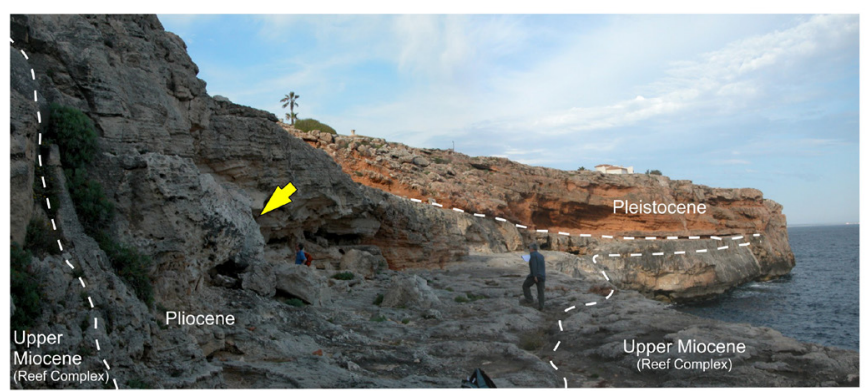

$\mathbf{N}$

$\mathbf{S}$

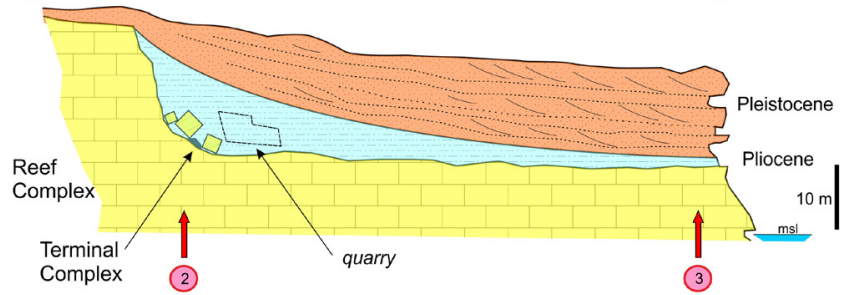

Fig. 6. Interpretative sketches of the stratigraphic sequence observable between sites 2 and 3 of Fig. 5. The yellow arrow in the top picture points to some Reef Complex blocks fallen from a coastal paleocliff and embedded within the Pliocene deposits. Small patches of the Messinian Terminal Complex (marked in the lower sketch) occur today at the base of this erosive paleocliff. 
east and southeast. Located at the top of the coastal cliff and truncating the Neogene sequence, the sedimentary eolian system could be classified as a cliff-top depositional system (Nielsen et al., 2004) although characterized by eolian transport across the cliff edge. Locally, at some entrances of the coastline, part of the cliff base is covered by Upper Pleistocene eolianites considered as cliff-front dunes (Clemmensen et al., 1997).

\section{GEOTHERMAL ACTIVITY IN SOUTHERN MALLORCA}

Geothermal phenomena, in the form of thermal springs discharging underground waters with temperatures higher than the annual average, are present in Mallorca although scarcely studied until now. Since ancient times (documented in the XV century), one spring was wellknown in the southern part of the island, the Font Santa de Sant Joan (Fig. 1), where a health resort was built in the middle of the nineteen century to exploit the hot water $\left(37^{\circ} \mathrm{C}\right)$. Nevertheless, this fact was not addressed by the scientific community until three decades ago, when the Instituto Geológico y Minero de España (IGME) conducted in 1984 a preliminary study of geothermal activity in the eastern part of Spain, including the Balearic Islands. As a result of these investigations, abundant wells with anomalous temperatures were documented in the Llucmajor area (IGME, 1984).

From an hydrogeologic and geochemical point of view, the geothermal activity originates in the shallowest aquifer of the Llucmajor Platform and Campos Basin (see location in Fig. 1), located in the Upper Miocene limestones and calcarenites, where nowadays more than 24 exploitation wells have recorded anomalous temperatures (López, 2007). The water table is about $125 \mathrm{~m}$ below the elevation datum of Llucmajor village, and the water temperature is near $50^{\circ} \mathrm{C}$ (López et al., 2004; López \& Mateos, 2006; López, 2007). Geochemical analysis clearly separates the calcium-sulfate thermal waters from the calcium-bicarbonate and chloride waters, characteristic of the natural composition of the shallow Upper Miocene aquifers in the rest of the island, although mixing of both in different degrees can be observed depending on the well location and depth (Mateos et al., 2005; López, 2007). The isotopic analyses of these thermal waters reveal their deep origin; there is no influence of sea water intrusion, as is demonstrated by the chloride/oxygen-18 ratio (López, 2007). Furthermore, the dissolved gases analyses indicate a sharp methane anomaly in the hottest waters, which may be due to the hydrocarbon traces in the deep Mesozoic basement deposits (Mateos et al., 2005; López, 2007). The data distribution of temperature, sulfates, silica, fluorine and lithium -recognized as geothermal indicators- suggest the existence of important SW-NE faults, as observed in seismic profiles (Mateos et al., 2005), which would allow the preferential flow direction of the thermal water from depth to the Upper Miocene aquifer. In the perpendicular direction a slow diffusion of geothermal indicators is observed.

Deep exploratory drilling $(700 \mathrm{~m})$ performed in the Llucmajor Platform revealed the presence of two different aquifers: the shallowest corresponding to the Upper
Miocene calcarenites and the deepest corresponding to the Paleogene milonitized carbonate conglomerates and sandstones. The latter shows an increase in temperature reaching at the deepest part $70^{\circ} \mathrm{C}$ (López et al., 2004; Mateos et al., 2005; López, 2007). Probably, these carbonate aquifers are fed by hot waters ascending, along SW-NE faults, from a deeper aquifer at an estimated temperature close to $90^{\circ} \mathrm{C}$ (López, 2007).

The geological setting where this geothermal activity takes place is part of the alpine belt that links the Balearics with the Betic Range, located at the southeast of the Iberian Peninsula. The carbonate lithologies, deposited almost continuously since the Middle Triassic, have been extensively affected by a complex compressive tectonic phase active from the Paleogene to the Middle Miocene. This compressive phase occurred within the context of the Western Mediterranean plate tectonics (Gelabert et al., 1992), which generated an environment suitable for the existence of geothermal anomalies. In that sense, thick carbonate deposits at great depths are present that can act as geothermal reservoirs (Mateos et al., 2005). Moreover, the southern part of Mallorca has been affected by Neogene normal faults (Gelabert et al., 1992; Sàbat et al., 2011), having a SW-NE trend, which produced relative uplift of the Llucmajor area and also caused the subsidence of the Campos basin (Fig. 1) at the southern end of the island. These graben-type structures were produced during the post-orogenic main extensional phase (TortonianMessinian); the faults delimitating these structures, or some vertical fractures subparallel to them (Ginés et al., 2008), permit hydraulic communication between the Mesozoic carbonate reservoirs and the Upper Miocene aquifer, where thermal anomalies are observed today.

More recently, feeble geothermal activity also has been evidenced during the systematic study of caves in the southern sector of the Mallorcan karst. In this respect, Merino et al. (2011a) reported anomalous high temperatures of the phreatic waters in Cova de sa Guitarreta $\left(27.1^{\circ} \mathrm{C}\right)$ and Pou de Can Carro $\left(23.6^{\circ} \mathrm{C}\right)$; both caves are located in the eastern edge of the Llucmajor Platform (Fig. 1), close to the Campos subsidence basin, their deepest passages reaching the water table of the Upper Miocene aquifer. The high temperatures together with specific morphological features, particularly from Cova des Pas de Vallgornera (Merino \& Fornós, 2010), have allowed to postulate the involvement of geothermal hypogene processes in the formation of this special cave system (Ginés et al., 2009b), as will be discussed in the next sections. Finally, it is worth mentioning the existence of another possible hypogenic cave (Cova Nova de Son Lluís; Ginés \& Ginés, 2006) located in the Mesozoic hills corresponding to the northeastern margin of the Llucmajor Platform (Fig. 1); this cave would support the existence of geothermally mediated speleogenesis affecting the folded basement that forms the Serres Centrals Range.

\section{MORPHOGENETIC INTERPRETATION OF THE CAVE}

Cova des Pas de Vallgornera is composed of a huge assemblage of passages and chambers quite 
heterogeneous from the morphogenetic point of view, with a surveyed length exceeding $74 \mathrm{~km}$. Its artificial entrance is located $400 \mathrm{~m}$ away from the coastline (Fig. 7), with some galleries almost reaching the coastal cliffs (less than $50 \mathrm{~m}$ away) but without a negotiable connection to the Mediterranean Sea; the maximum inland penetration is around $1.5 \mathrm{~km}$. The area containing the cave is approximately $2.5 \mathrm{~km}^{2}$, giving a passage density value close to $30 \mathrm{~km} / \mathrm{km}^{2}$. This figure is higher than the values reported from other extensive cave systems in coastal settings, like Quintana Roo, Mexico $\left(6.5\right.$ to $\left.19 \mathrm{~km} / \mathrm{km}^{2}\right)$, but substantially lower than densities of passages from some hypogenic caves both in limestone or gypsum $\left(300 \mathrm{~km} / \mathrm{km}^{2}\right)$ according to the values supplied by Smart et al. (2006).

Most of the cave development occurs near the water table, which is linked to the current sea level, whereas there are also extensive passages located both above and below present sea level (Merino et al., 2011b). Underwater extensions are significant (Gràcia et al., 2009a) totalizing nowadays over $17 \mathrm{~km}$ of galleries. A detailed description of the cave is available in the paper by Merino et al. (2014) also included in this issue. Several morphologic aspects will be treated now in order to contribute later on to the speleogenetic interpretation of this cavern. The location of the main sectors and galleries of the cave has been compiled in
Fig. 7 with the aim of providing a helpful tool that can facilitate this discussion.

\section{Main morphological trends}

The general morphology of the cave is rather variegated, its most prominent characteristic being the coexistence of collapse chambers together with extensive arrays of phreatic solutional galleries. The topographical arrangement of these two-fold categories of passages shows evident regularities in a first look, mainly consisting in a remarkable abundance of collapse features in the sections of the cave closer to the coastline. This really relevant fact is related to the spatial distribution of the Upper Miocene reef front facies (Ginés et al., 2008) as will be in depth discussed later on.

Referring to the solutional galleries, the dominant morphologies are spongework mazes and passages that are developed particularly in the south-western seaward sectors of the cave. On the other hand, in the inland north-eastern sections, the presence of shallow phreatic solutional conduits is the rule. These conduits, which characterize the inner part of the cave, formed along prominent SW-NE fractures (Fig. 7) and are markedly horizontal and without vertical loopings.

In whatever case, it is worth remarking that solutional sculpturing does not include true scallops, with

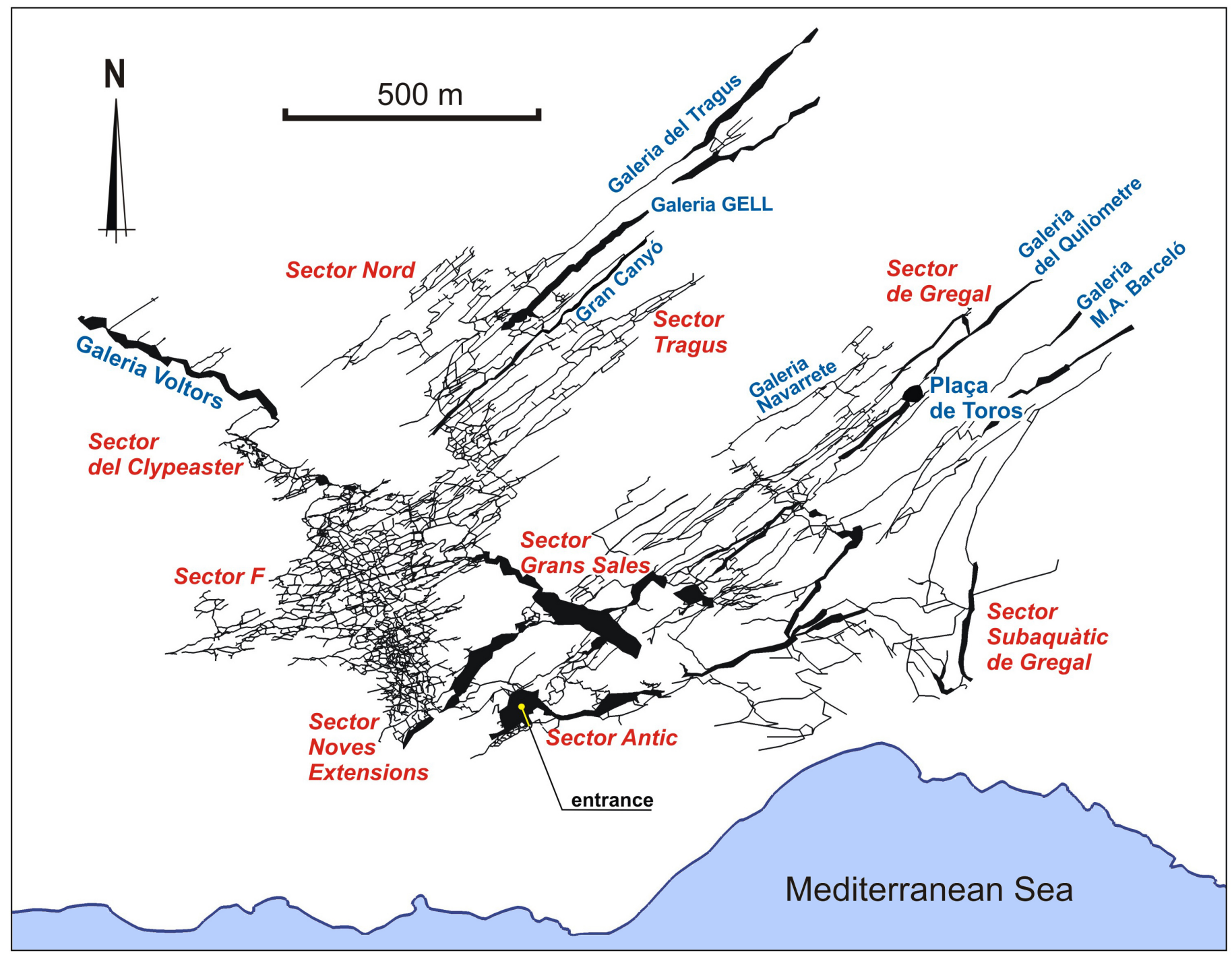

Fig. 7. Simplified survey of the cave showing the location of the main sectors and passages referred in the text. 
the dominant morphologies being different kinds of centimetric to even metric dissolution pockets, in many cases arranged along bevels and notch-like features. The diversity of dissolution forms is quite important, being the subject of detailed descriptions in Gràcia et al. (2009b, 2009c). Special mention should be made about the presence of solutional ascending features, pointing towards the participation of hypogene processes in the genesis of the cave (Fornós et al., 2011).

Finally, the present-day appearance of Cova des Pas de Vallgornera is characterized by a large number of speleothems that are widespread all along its different sections. The diversity of speleothems is really impressive, including underwater crystallizations related to Upper Pleistocene and Holocene sea-stands (Dorale et al., 2010; Tuccimei et al., 2010); these phreatic carbonate deposits provide clear evidence about the control that sea level has exercised during the entire evolution of the cave and, in particular, on the most recent geomorphological events recorded inside it.

\section{Cave patterns and lithologic variability}

In broad terms, the plan pattern of this cavern fits into the wide category of maze caves, according to the systematization established by Palmer (1991, 2007). However the maze pattern of the cave is not homogeneous, showing a two-fold configuration already cited when referring to its general morphological trends. In this respect a clear dichotomy arises again between the seaward part of the cave system, where spongiform-ramiform patterns are dominant, and the inland sectors consisting in a crude labyrinth of structurally controlled passages developed in a SW-NE direction (Fig. 8).

The above-mentioned distribution of the cave patterns is related to the architecture and lithological variability (both laterally and vertically) of the Upper Miocene Reef Complex, as has been postulated in some previous papers (Ginés et al., 2008, 2009a). The different depositional environments represented within the Reef Complex determine well-defined morphogenetic assemblages as a function of the lithological and hydrological characteristics of the bedrock in this eogenetic coastal karst. So, a first clear differentiation could be envisaged concerning the morphogenetic suite observable in the south-western seaward part of the system -excavated in the reef front facies- as opposed to the inland inner sectors developed in the less permeable back reef facies (Fig. 8).

Starting with the south-western part of the cave (which comprises the following sections: Sector Antic, Sector Noves Extensions, Sector F, Sector Grans Sales and Sector del Clypeaster; all of them depicted in Fig. 7), the plan is predominantly labyrinthine but there are many collapse chambers interspersed within a general spongiform array of passages (Palmer, 2007); it is not possible to recognize any kind of structural network pattern in the above mentioned sectors. The passages of this part are medium-sized (in the order of a few meters maximum) and were formed in the very porous and permeable reef front facies, where spongework solutional features occur together with rather generalized breakdown processes. The coastal phreatic mixing has greatly increased the porosity of the rock by dissolving the coral structures, which are ubiquitous in these sectors of the cave, thereby causing spectacular differential dissolution phenomena (Fig. 9). The preferential dissolution of coral constructions has favored the collapse processes, so abundant in the seaward south-western sectors of the cave. The resulting plan pattern is a spongiform maze ranging in places to a rather ramiform pattern (Palmer, 2007) owing to the presence of extensive breakdown chambers that are scattered within these cave sections, being normally accessible through narrow collapse constrictions. Special note should be taken of Galeria Voltors, a paradigmatic example of speleogenesis totally conditioned by the reef barrier topography (Figs. 7 and 8 ). This unique passage develops over $500 \mathrm{~m}$ in the $\mathrm{NW}$ direction due to the solutional phreatic excavation of the coral barrier, with a mean width exceeding $10 \mathrm{~m}$; the gallery lacks any structural guidance and follows a wandering course rigidly adapted to the reef front architecture.

On the other hand, a quite different situation takes place in the extensive assemblage of passages developing more than $1 \mathrm{~km}$ inland towards NE (which includes the following sections: Sector Nord, Sector Tragus, Sector de Gregal and Sector Subaquàtic de Gregal). The width of the galleries range from less than a meter to more than $10 \mathrm{~m}$ particularly when breakdown processes have enlarged them, as for example in Galeria GELL and Gran Canyó. These inner passages are developed in the back reef deposits (Fig. 10), specifically in the outer lagoon facies of the Upper Miocene Reef Complex (Pomar et al., 1996). These back reef carbonates are very massive and less permeable than the reef front facies, owing to their lower porosity and more calcisiltitic character. The extensive array of passages existing in the outer lagoon facies are joint-controlled phreatic galleries excavated along major SW-NE fractures (Fig. 8), that run parallel to the extensional faults responsible for the Campos subsidence basin located to the SE of the cave area (Fig. 1). The pattern of the passages corresponding to the outer lagoon facies may be defined as an irregular 2D maze, with a clear SW-NE alignment. This structural trend is determinant regarding the results obtained through the statistical treatment of passage orientations: almost $42 \%$ of the total length of the segments from the topographical survey is oriented in the range $\mathrm{N} 40-70^{\circ} \mathrm{E}$ (Fig. 11). Finally, it must be mentioned that the long galleries forming the inland sectors of the cave, display from time to time some breakdown chambers where coral patches are interspersed within the back reef carbonates. The Plaça de Toros, located along Galeria del Quilòmetre, is a clear example of these local collapse phenomena associated with the dissolution of isolated coral structures.

Another important lithological change occurs toward the north-eastern ends of the long passages that integrate the inner part of the cave system (Fig. 8). In this sense, the termination of the main galleries corresponding to Sector Tragus and Sector de Gregal seems to be explained by the appearance of deposits attributed to the inner lagoon facies, within 


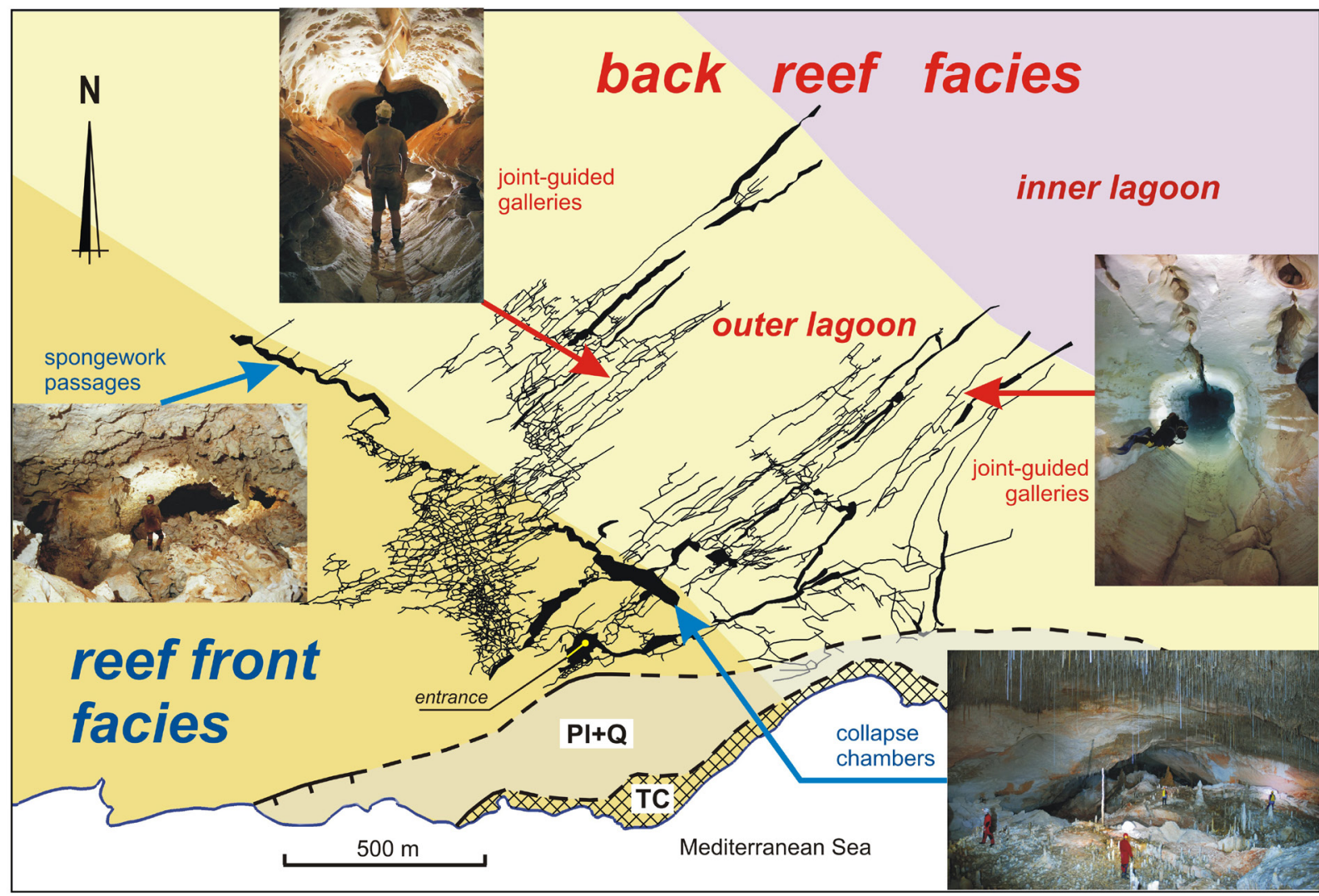

Fig. 8. The plan pattern of Cova des Pas de Vallgornera is tightly constrained by the different facies within the Upper Miocene Reef Complex in the Llucmajor Platform of southern Mallorca. The most characteristic morphological trends, linked to the lithologic variability, are illustrated by the photographic insets (see additional explanations in the text). The Messinian Terminal Complex (TC) and the Plio-Quaternary beach and dune deposits $(\mathrm{Pl}+\mathrm{Q})$ outcrop in a fragmentary way only along the coastal cliffs of the area. Right-side photos by Antoni Cirer (up) and Bogdan P. Onac (down).
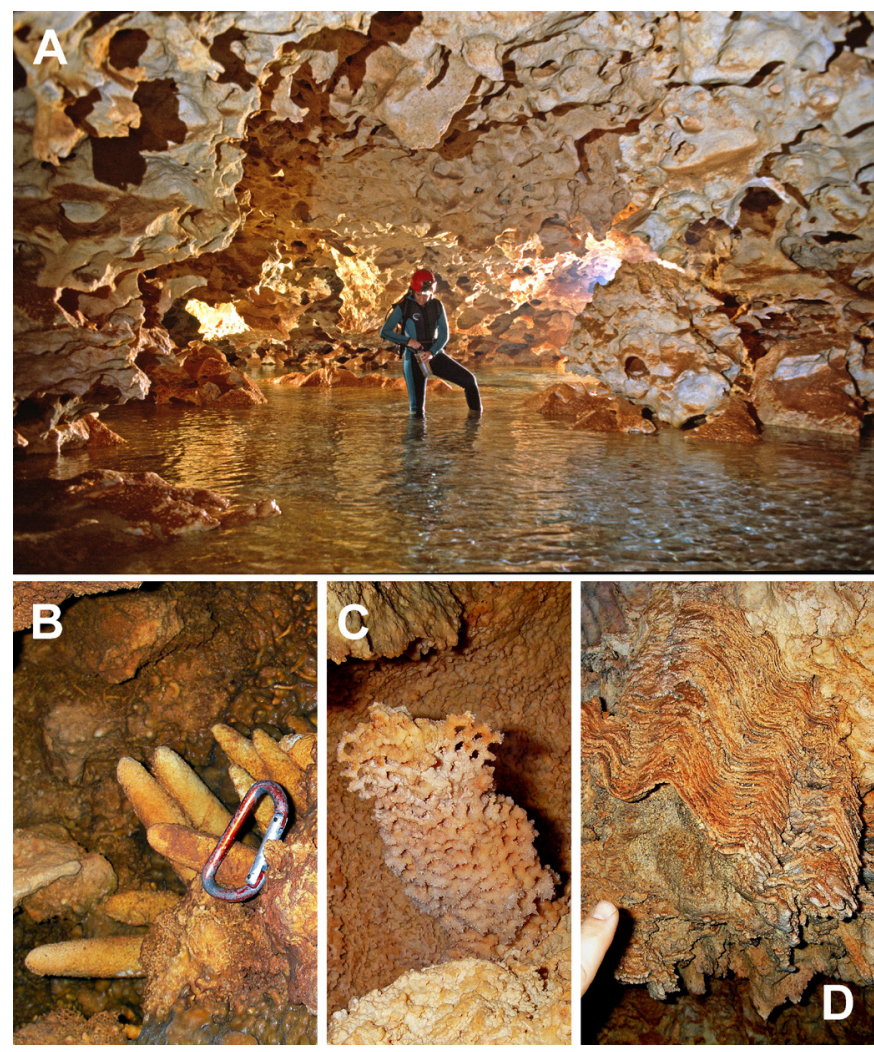

Fig. 9. Solutional features in the passages and chambers corresponding to the reef front facies. A) Spongework labyrinthine galleries developed close to the current water table, in Sector Noves Extensions; B) Casts related to bivalves that were boring the coral framework during the formation of the Upper Miocene reef; the corals have been almost totally removed by subsequent solutional coastal mixing processes, forming vugs and voids up to meters in size (Sector del Clypeaster); C and D) detail views of coral constructions strongly affected by dissolution processes. the Upper Miocene Reef Complex (Pomar et al., 1996). In the terminal passages of the above referred sectors the rock becomes less massive, with calcisiltitic and marly materials disposed in beds whose thickness is decimetric to metric. In the current state of exploration, all the major passages trending inland to the $\mathrm{NE}$ (including the underwater ones, as for instance Galeria M.A. Barceló) have abrupt endings at a distance of around $1 \mathrm{~km}$ away from the deduced location of the Upper Tortonian reef barrier (Fig. 8).

Some comments must be made about another relevant geological unconformity, related to the outcropping of the so-called Terminal Complex (Messinian) as well as the Plio-Quaternary beach and dune deposits. These materials are only present near the coastline cliffs, being laterally attached to an erosive paleocliff affecting the Upper Miocene carbonates which form the Reef Complex (Figs. 5 and 8). This unconformity is rather coincident with the southern limits of the cave system, where the conduits from Sector Subaquàtic de Gregal turn towards the south and almost reach the coastline (Fig. 8). Probably the littoral breaching of these Messinian to Plio-Quaternary materials has played some hydrological role in the configuration of the network of passages developed within the carbonates of the Reef Complex, favoring its bending towards the south because of the sea cliff retreat and consequent erosion of these deposits that have acted as an aquitard.

As a brief recapitulation of the lithological constraints, three diverse morphogenetic settings can be individualized which are conditioned by the sedimentological and textural characteristics of the 

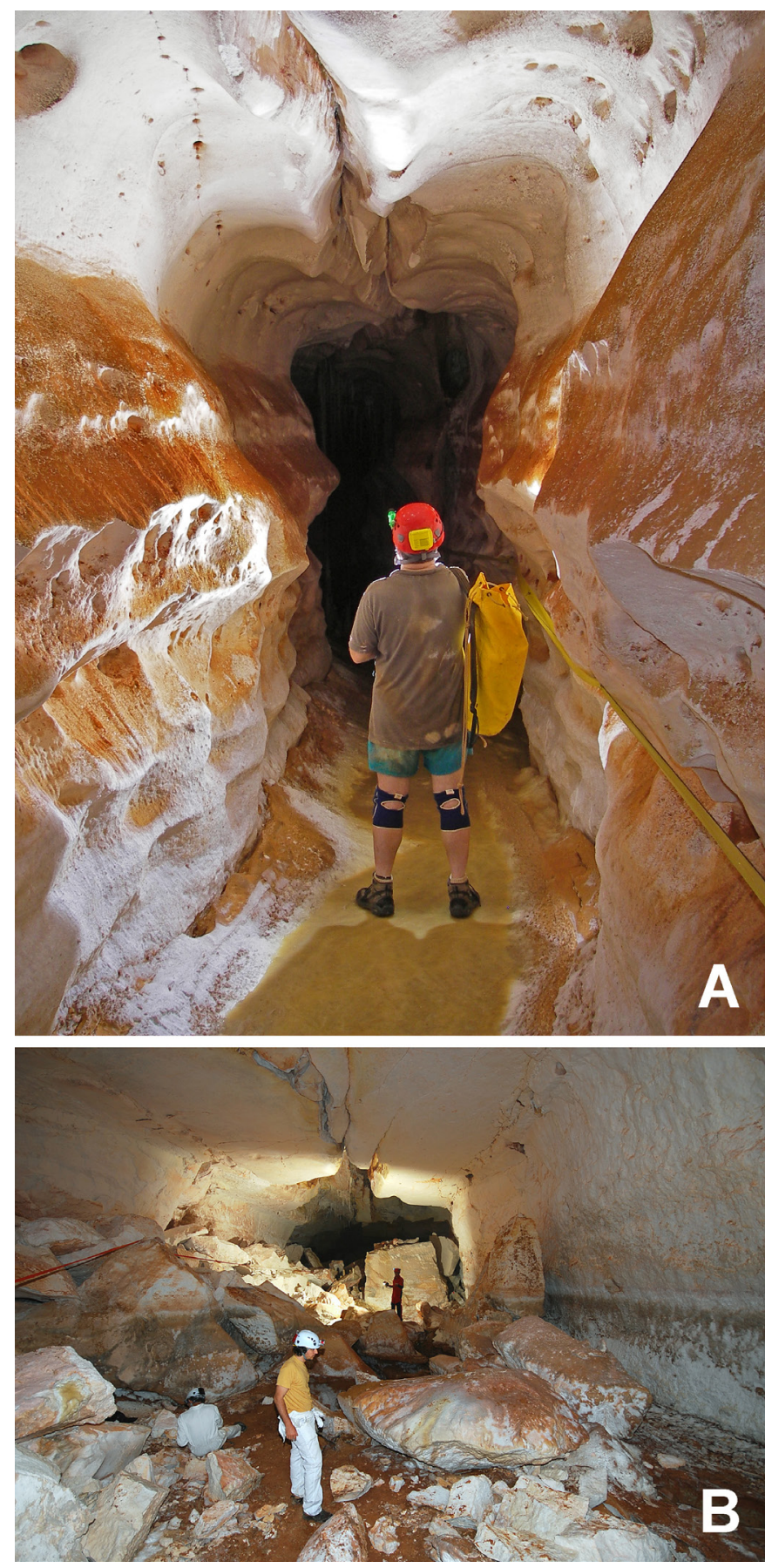

Fig. 10. Passage features developed within the back reef facies. A) View of a gallery in the upper tier (Sector Tragus) shaped with spectacular dissolution features (notches beveled by wall facets, pockets of diverse size, etc.) and excavated along a prominent fracture; B) The northernmost end of Galeria del Tragus runs structurally controlled by SW-NE joints clearly visible in its ceiling, but has became greatly enlarged by breakdown (photo by Miquel A. Perelló).

Upper Miocene Reef Complex (Ginés et al., 2008, 2009a; Fornós et al., 2010a). It is possible to distinguish: 1) the very porous and permeable reef front facies, with framestone and rudstone textures, where spongework passages and breakdown passages are the rule; 2) the massive calcarenitic and/or calcisiltitic outer lagoon facies, with variable wackestone, packstone and grainstone textures, where joint-guided NW-SE conduits are dominant; and 3) the inner lagoon facies, that are well-bedded as well as increasingly calcisiltitic and marly (wackestone textures) and represent the inland limit of the cave passages. These three lithological settings are arranged more or less parallel from SW to

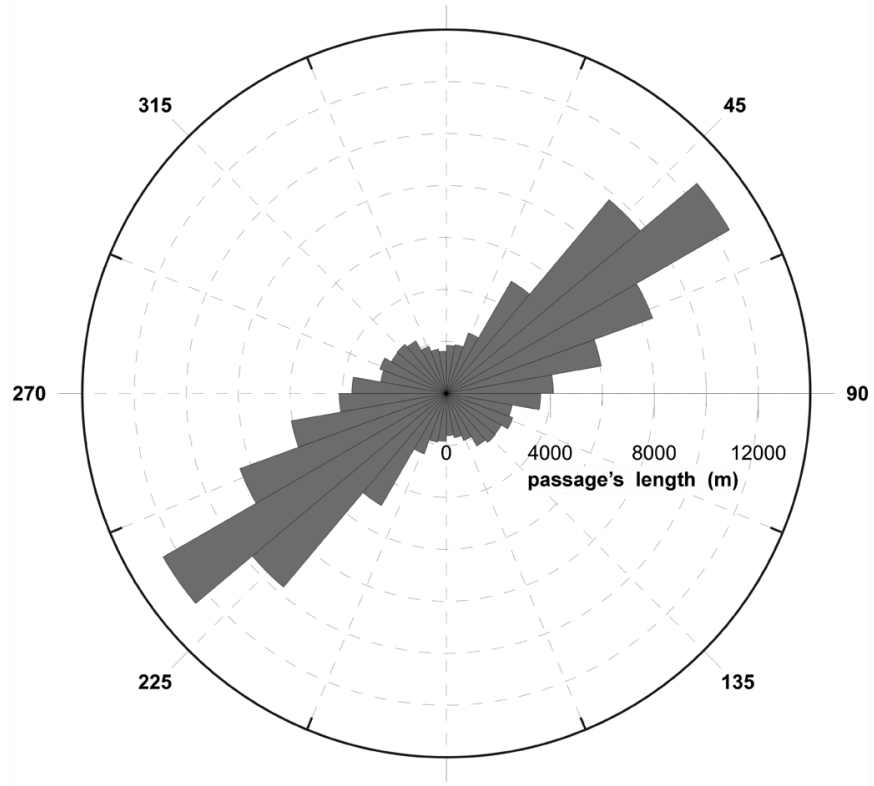

180

Fig. 11. Quantitative diagram of orientations based on the azimuths of the polygonal segments from the whole cave survey (total measured development 73,672 m).

$\mathrm{NE}$, reflecting the architecture of the Upper Miocene Reef Complex (Fig. 8). The described distribution of the different facies also shows some vertical variations linked to the sedimentological history of the whole Reef Complex. For example, part of the Sector F upper maze is located in the back reef facies (with packstone textures) corresponding to a depositional sequence later than the main reef constructions, located at lower elevations and hosting some sections of the cave system developed close to the present-day water table. The whole cave has been formed in the different facies of the Upper Tortonian-Lower Messinian Reef Complex, without penetrating the more recent deposits outcropping along the littoral fringe (Messinian Terminal Complex and Plio-Quaternary littoral sediments).

\section{Development of the cave in its vertical dimension}

Looking at the disposition of passages in Cova des Pas de Vallgornera concerning their elevation, it is possible to distinguish roughly two main tiers of galleries and chambers developed respectively above or close to the current water table, the later including an extensive array of underwater extensions. This relatively simple configuration comprising two principal tiers appears substantially modified by breakdown processes that produce the disorganization of the initial solutional voids through the enlargement and upwards migration of the passages.

In general terms, within the air-filled part of the cave system it is clearly individualized a lower tier of solutional galleries and collapse chambers, located at the water table or slightly above it; this water table story is outstanding due to the presence of very extensive brackish pools of unusual beauty. On the other hand an upper tier, mainly consisting in several maze areas, develops at elevations between +7 and $+11 \mathrm{~m}$ above the current sea level, although its altimetric disposition is far from being uniform. This upper story includes some collapse-enlarged passages, but not as abundant as those 
in the lower tier. A simplified graphical overview of the elevation at which the floors of the passages are located is quite illustrative (Fig. 12), showing a general distribution of the highest mazes and galleries in the NW half of the cave. As opposite, the lower tier of passages running close to the water table is located in the SE part of the cave system, together with the extensive underwater sections that reach maximum depths of $-8 \mathrm{~m}$ below the sea level.

It must be also mentioned that a superposition of the two main tiers occurs at some spots of the cave. Particularly, in the southern limits of the system the lower maze (corresponding to the Noves Extensions sector) runs below an extensive area of the Sector F upper story (Fig. 12), but there is no a direct connection between these two superposed mazes. In a similar way, in the area leading to Sector del Clypeaster, the upper maze is connected to a net of narrow corridors developed at the water table that allows access to the spectacular reef front gallery constituted by Galeria Voltors.

The altimetric distribution of the passages shows some additional particularities, for example the progressive descent of the northernmost Galeria del Tragus in the NE direction before reaching the water table (Fig. 12), or the important ascending trend of Galeria Voltors towards its NW end, where an elevation near $+30 \mathrm{~m}$ a.s.l. is attained.

With the aim of better illustrating the elevation of the inner sectors of the cave, a transverse schematic profile of the back reef passages is depicted in Fig. 13; the profile has been constructed projecting on a NW$\mathrm{SE}$ vertical plane the elevation data from the survey taken from the main passages in Sector Tragus, Sector de Gregal and Sector Subaquàtic de Gregal. In this sketch, the vertical scale is greatly exaggerated (elevations ranging only from -8 to $+15 \mathrm{~m}$ a.s.1.) with respect to the horizontal axis of the profile, which is $1,200 \mathrm{~m}$ long. The vertical dimension of the galleries is real, but their widths are not drawn to scale for a more useful representation. The color-code used for elevation intervals in this drawing is similar to that in Fig. 12.

It is clear that the northernmost back reef passages (those from Sector Tragus) are higher than the conduits developed to the SE (Sector de Gregal and Sector Subaquàtic de Gregal), with some disturbances introduced by the involvement of collapse processes. As a general trend resulting from the observation of Fig. 13, two principal tiers of back reef galleries can be distinguished, the lowest of them being also present in some recently explored underwater passages existing towards the north in the vicinity of Gran Canyo and Galeria GELL.

In spite of this more or less evident disposition in two principal tiers -the highest +7 to $+11 \mathrm{~m}$ mazes on one hand, and the water table and underwater sections on the other hand- it is yet not possible to discuss about

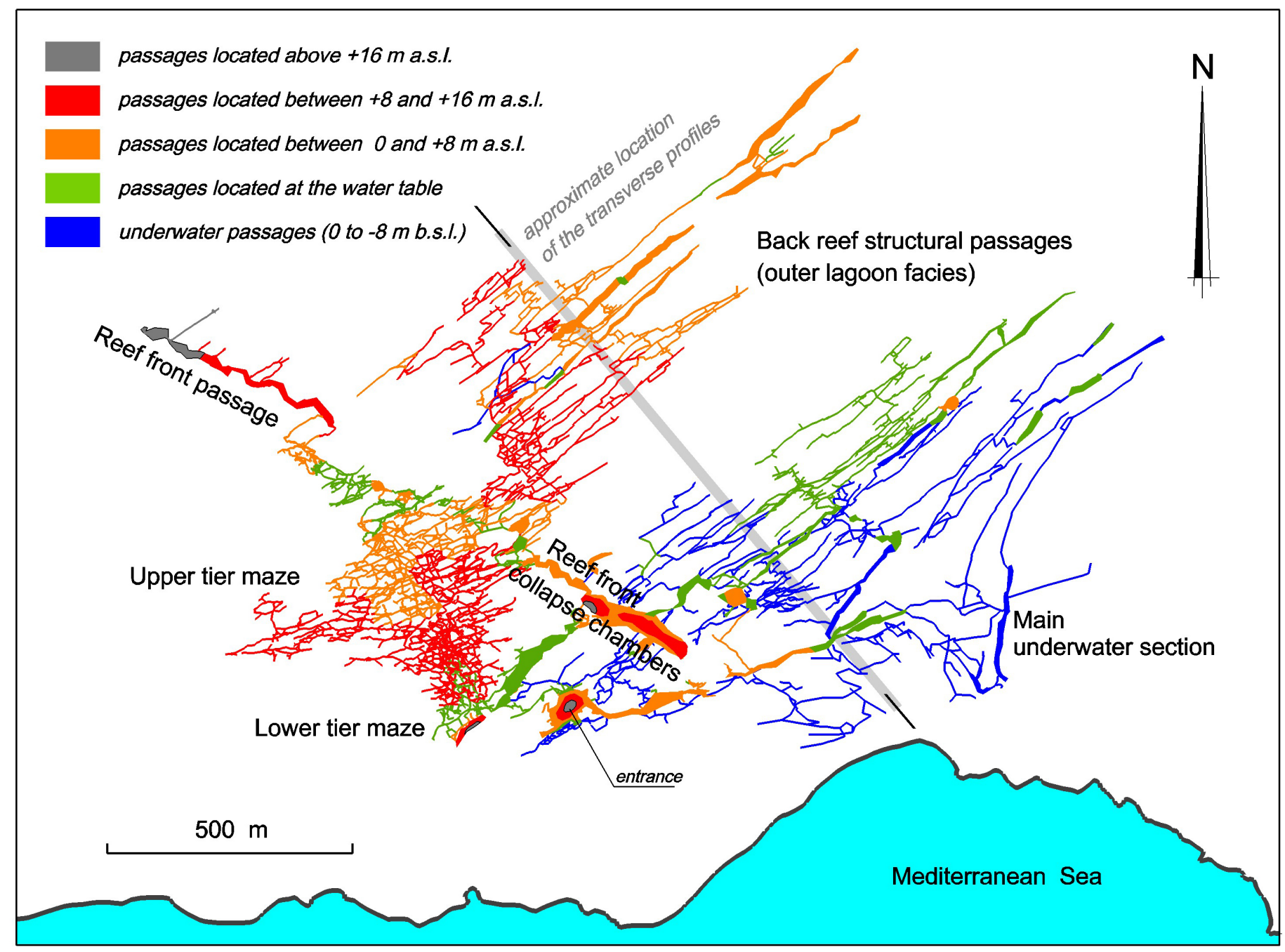

Fig. 12. Simplified survey of Cova des Pas de Vallgornera depicting the elevation distribution of passages and chambers. Notice the existence of two main tiers, the upper one located several meters above sea level (orange, red and dark grey colors), and the lower developed close to or below the current coastal water table (green and blue colors). Detailed explanations are supplied in the text (section on the vertical arrangement of the cave system). 


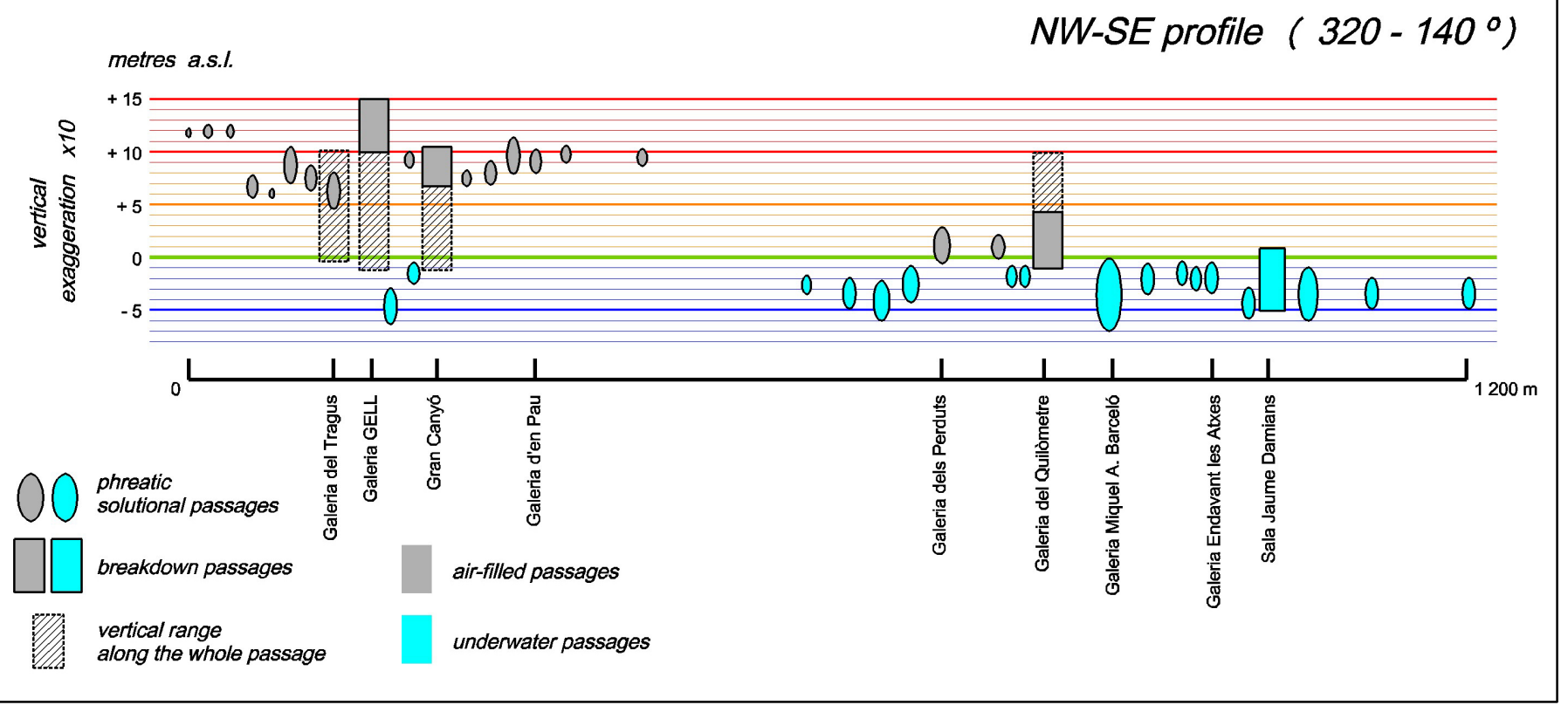

Fig. 13. Transverse schematic profile of the back reef passages. The vertical dimension of the galleries is real (but exaggerated with respect to the horizontal axis of the profile) whereas their widths are not scaled for a more clear representation. Note the lower elevation of the south-eastern passages and the existence of some underwater galleries also close to Gran Canyó and Galeria GELL (additional explanations in the text).

clear levels of passages on the basis of any lithological or erosional evidence. Additionally, it must be taken into account that the sea-controlled base level has fluctuated extensively from Messinian times to present, so it is difficult to make any precise morphogenetic and/or geochronological reconstruction, considering furthermore the assumed pre-Quaternary age of speleogenesis (see the later discussion on this matter in next paragraphs). Therefore, geomorphologic interpretations like that proposed by Florea et al. (2007) for underwater cave systems in Florida are valid in a broad sense (i.e. sea level controls the speleogenetic processes) but can hardly supply more precise data, at least in our case. Moreover, and contributing to the complex situation in Cova des Pas de Vallgornera, the elevation of the Pliocene and Quaternary shoreline deposits (already discussed when presenting the lithostratigraphy of the area) supplies evidence on Plio-Quaternary tectonic disturbances that could have ultimately affected the altimetric distribution of the cave passages.

\section{Solutional features and their diagnostic significance}

Although a thorough discussion of dissolution morphologies is not the target of this section, some comments must be made about those features that could be relevant when trying to ascertain the processes involved in the cave genesis. Besides the profusion of spongework and other morphologies typically ascribed to coastal mixing environments (Mylroie \& Mylroie, 2009), there are in Cova des Pas de Vallgornera some assemblages of dissolution features that can be considered diagnostic regarding the specificity of their forming mechanisms; these features fall into two broad categories, not specifically related to karstification in coastal environments. So, whereas the seaward part of the cave-developed in the porous reef front facies - is dominated by a suite of forms quite common in the littoral caves of Mallorca (Gràcia et al., 2009c, 2011a) the inland part of the system contains some solutional features, which must be highlighted because they do not fit the general morphogenetic frame of karst in the southeastern coast of the island, as documented in several papers (Ginés \& Ginés, 2007; Gràcia et al., 2011b; Ginés et al., 2013).

A first group of forms provided with a clear diagnostic signification are the abundant solutional conduits (in the back reef facies) whose morphological suite denotes an effective and concentrated drainage corresponding to ancient water table positions, obviously sea level controlled. These conduits show well-developed solution notches, usually with their lower sides beveled by wall facets (Fig. 10). Many of these notch-like morphologies are integrated by a string of decimetric to metric horizontal pockets that suggest rather slow flow, but without the presence of small-scale flow features like scallops. Certainly, the presence of solutional galleries in the coastal karst of Mallorca is relatively frequent in those sectors of underwater caves not affected by generalized breakdown phenomena -as happens in other localities like Cova des Coll and Cova de sa Gleda- but usually these passages are integrated in a general spongework pattern (Gràcia et al. 2005, 2010), lacking clear evidence of a substantial dynamic flow through the conduits.

The second group of forms that deserves special mention are rising-flow solutional morphologies (sensu Klimchouk, 2007, 2009), that are present particularly in the inland back reef passages. The most diagnostic features of this category are ascending dissolution channels of very diverse dimensions (Fig. 14), which have been interpreted as having a hypogene origin (Ginés et al., 2008, 2009a). The widths of these features range from millimeters to some decimeters (sometimes more than $1 \mathrm{~m}$ long) and develop vertically along overhanging walls. Many of these morphologies are similar to the bubble trails documented by Palmer (2007) and Audra et al. (2009), and their formation by ascending aggressive flows can be envisaged due to the lack of carbonate precipitates associated with $\mathrm{CO}_{2}$ degassing at the water table (folia, calcite rafts, etc.). These features occur at 


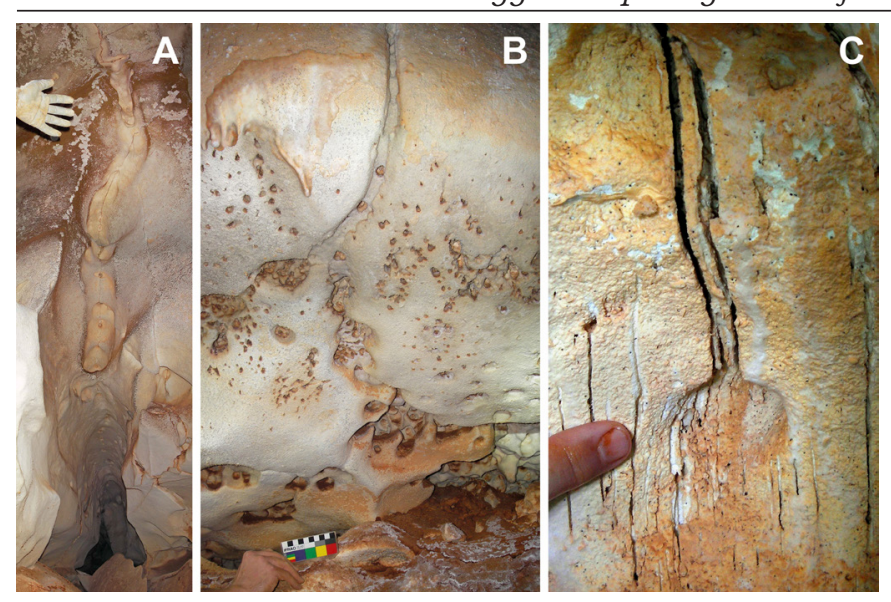

Fig. 14. Solutional ascending features are particularly abundant in the inland parts of the cave, being specially well-represented in some passages of Sector de Gregal; they are the most diagnostic morphologies pointing towards the involvement of hypogenic processes in the genesis of the cave system. A) Rounded rising channel longer than one meter and relatively wide, starting from a narrow lateral feeder; B) Ascending solutional channel developed from a lateral feeding point and showing a rather erratic course along the overhanging wall; note the abundance of small alveoli, even along the channel, probably related to dissolution boosted by the trapping of gas bubbles; C) Sharp solutional ascending grooves, whose widths are millimetric, frequently begin from rounded centimetric pockets.

any elevation within the inland back reef passages, from underwater galleries to the upper maze areas located more than $+7 \mathrm{~m}$ a.s.1.; they are very abundant and conspicuous, for example, in Galeria del Quilòmetre and the passages leading to it. These kinds of rising channels are integrated within a more extensive suite of forms including cupolas, feeder-like vertical hollows, blind galleries, etc. (Fornós et al., 2011; Merino et al., 2011a), pointing towards an involvement of hypogenic processes linked to the geothermal anomalies in the area (López \& Mateos, 2006; López, 2007). There is no evidence for the involvement of $\mathrm{H}_{2} \mathrm{~S}$ in the genesis of the system, $\mathrm{CO}_{2}$-rich deep recharge and/or the cooling of thermal waters being the most probable sources of aggressiveness explaining these rising features.

\section{Sediments and their distribution}

Detrital sedimentation is not a relevant phenomenon in the whole cave system. Clayey and silty sediments are scarce, but do occur in the galleries of the innermost part of the cave as patchy accumulations rarely exceeding $20 \mathrm{~cm}$ in thickness, both in the air-filled and underwater passages. The autochthonous sediments are similar to those previously described in Mallorcan coastal caves (Fornós et al., 2009), frequently being a mixed sedimentation including carbonate particles detached from the walls, together with clay and silt deposits derived from the infiltration of soil materials to the underlying voids. Despite the general scarcity of detrital infillings, a particularly different situation occurs in the northernmost end of the cave (the so-called Galeria del Tragus; see location in Fig. 7) where an important sequence of sediments is present, which hosts a very rich paleontological deposit. A detailed overview of sedimentary processes acting in the cave is supplied by Fornós et al. (2014).

On the one hand, the clayey sedimentation is not very widespread and it seems to be preferentially deposited in some secondary passages, like for instance Galeria Navarrete (Fig. 7), which exhibits the thickest accumulation of this kind of deposit (nearly $40 \mathrm{~cm}$ ). This distribution is probably related to a rather substantial flow in the main drainage conduits, so preventing the accumulation of sediments that are preferentially deposited in the secondary routes of the minor lateral galleries.

On the other hand, the already referred sequence in Galeria del Tragus is completely different (Fornós et al., 2010b). It is a $2.5 \mathrm{~m}$ thick accumulation of sands and silty deposits of allochthonous origin that host very interesting osteological remains (Bover et al., 2014), linked to the existence of an ancient entrance to the cave system. The extension of these deposits, filling up more than $200 \mathrm{~m}$ of Galeria del Tragus, points towards important episodes of surficial recharge perhaps related to some sinks from major surface ravines, like Torrent de Garonda running some hundred meters to the north.

Although completely different, both types of sediments suggest a noteworthy participation of the meteoric recharge in the formation of the innermost passages of the cave. However, the involvement of other active genetic processes is not excluded.

\section{SPELEOGENETIC APPROACH}

Coastal caves in the Upper Miocene rocks of south and eastern Mallorca have been attributed historically to different genetic mechanisms: marine erosion (Martel, 1896), erosive action of underground rivers (Maheu, 1912; Faura y Sans, 1926; Darder, 1930) or, more recently, phreatic dissolution voids affected by collapse processes (Ginés \& Ginés, 1977). Nowadays there is a wide consensus about the formation of caves in this area as a result of coastal mixing dissolution and extensive breakdown, in a geomorphic setting fully controlled by sea level history (Ginés \& Ginés, 1992, 2007, 2011; Gràcia et al., 2011b). However the resulting caves, in the Mallorcan case, don't fit strictly the flank margin model of cave evolution (Mylroie \& Carew, 1990), which is internationally adopted as the current paradigm in littoral speleogenesis. In fact, the geologic setting of Mallorca is rather similar to the complex island category of the Carbonate Island Karst Model (Mylroie \& Mylroie, 2007) that considers a complicated situation regarding lithologic and tectonic constraints. In the case of Cova des Pas de Vallgornera, the speleogenetic interpretation becomes even more complex, among other circumstances, because of the great length of the cave system together with its noticeable morphological diversity favored by the local geology; namely, the differences in hydrologic behavior between the distinct reef facies.

\section{Involved speleogenetic mechanisms}

Dealing with the aforementioned diversity of underground landscapes, the south-western seaward sectors of the cave are characterized by a morphological assemblage that could be compatible with dissolution in the coastal mixing zone, as has been invoked when studying the abundant littoral caves from the Migjorn region of Mallorca Island (Ginés \& Ginés, 2007; Gràcia et al., 2011a; Ginés et al., 2013). In these seaward 
sections of the cave system, a boost of aggressiveness associated with the mixing of fresh- and sea-water (Plummer, 1975; Back et al., 1984) has presumably led to the preferential dissolution of coral constructions, within the Upper Miocene eogenetic carbonates, creating a profusion of voids arranged in a roughly spongiform maze pattern (Palmer, 2007). The pervasive spongework sculpturing seems to be the result of a diffuse-flow phreatic dissolution acting on these extremely porous and permeable reef front facies. In addition, collapse processes have also been determinant from the morphogenetic point of view, causing the disorganization of the solutional voids that were formed by mixing dissolution in the more lithologically favorable parts of the littoral fringe. The geochemical aggressiveness linked to the coastal mixing zone must be responsible as well for the removal of a substantial part of the rock blocks produced by breakdown mechanisms. In this respect some other Mallorcan caves, like Cova de sa Gleda (in Manacor), exhibit solutional features carved at the current halocline which have cut across the rock walls and even the submerged vadose speleothems (Gràcia et al., 2010, 2011a), but in Cova des Pas de Vallgornera there is no clear evidence of dissolution being active in the current mixing zone.

With a completely different morphology, the inland sectors of the cave system consist of long conduits forming an irregular network maze developed along prominent joints and fractures. These even kilometric passages correspond to speleogenetic processes that happened in shallow phreatic conditions, within a coastal aquifer effectively drained by a couple of rather parallel master conduits excavated in the back reef carbonates (outer lagoon facies, according to Pomar et al., 1996). As mentioned in previous sections, small-scale solutional forms indicative of a highly dynamic hydrological flow (i.e. scallops) are not present. Although the presence of well-developed drainage galleries is not the rule when talking about eogenetic karstification (Vacher \& Mylroie, 2002), the existence of real solutional conduits has been reported in cases like Florida (Moore et al., 2010) where dissolution by meteoric waters is capable of forming drainage systems, favored by the action of aggressive waters even at the rock matrix scale.

The elongated 2D maze pattern of the inner sectors of the cave seems to integrate a poorly organized drainage system, related to a diffuse recharge occurring directly over the moderate to highly permeable rocks of the Upper Miocene Reef Complex. In spite of the diffuse authigenic recharge and the current low rainfall (approx. $400 \mathrm{~mm} / \mathrm{yr}$ ), some important recharge episodes have presumably occurred in wetter Plio-Quaternary events, evidenced by locally important sediment accumulations existing in the cave (Fornós et al., 2010b). The presence of Torrent de Garonda, a creek that runs relatively close to the northern end of Galeria del Tragus, could have contributed to the meteoric recharge of the aquifer through losses from this episodic water course.

Finally, it must be remarked the presence of solutional ascending channels in the inland sectors of the cave, together with some other morphologies -feeder-like vertical hollows, cupolas, dead-end passages, etc.- of a plausible hypogene origin (Ginés et al., 2009b; Fornós et al., 2011), in the sense formulated by Klimchouk (2007, 2009). Other possible evidence of hypogene karstification consists in crusts and other precipitates rich in $\mathrm{Mn}$ and $\mathrm{Fe}$, as well as a peculiar assemblage of uncommon minerals (celestine, strontianite, barite, nordstrandite, etc.) existing as post-drainage deposits close to the vents located in the floor of some passages (Merino et al., 2009; Fornós et al., 2010a; Onac et al., 2014). The above described phenomena could be explained by a deep hypogenic recharge from the Mesozoic basement, linked to the geothermal anomalies associated with the extensional faults limiting the western edge of the Campos subsidence basin (Fig. 1); this basal recharge is supported by the non-functional hypogene features described in this cave as well as isolated geothermal evidence from other cavities and wells of the surrounding area (López \& Mateos, 2006; Merino et al., 2011a).

The genetic complexity illustrated by Cova des Pas de Vallgornera is depicted in Fig. 15, where the interaction of three speleogenetic agents is postulated: 1) phreatic dissolution in the coastal mixing zone, 2) epigenic karstification related to the underground drainage of meteoric precipitations, and 3) deep hypogenic recharge linked to the geothermal anomalies documented in the area. The participation of these three agents is strongly controlled by lateral and vertical variations in permeability, within an unconfined littoral aquifer, as a consequence of the internal architecture of the Upper Miocene reef. The resulting cave system displays a clear drainage functionality through conduits in the less permeable back reef facies, whereas in the highly permeable front reef facies the groundwater flow takes place basically through the primary porosity of the rock, enhanced by the coastal geochemical aggressiveness. This panorama shows little resemblance to the flank margin cave paradigm (Mylroie \& Carew, 1990) whereas, however, has important similarities with the Quintana Roo caves from Yucatan Peninsula, as documented in Smart et al. (2006), with the particularity of the possible hypogene influence reported in the Mallorcan case, and even in the Yucatan Platform (Thomas, 2010). As argued by Smart et al. (2006), the extension of the catchment area acts as a limiting factor that forces the switch from one model to the other, a fact also observable in the Balearic archipelago where typical flank margin caves are exclusively well-represented in the small island of Formentera (Ginés et al., 2008) whose area is only $83 \mathrm{~km}^{2}$.

\section{Base level position and evolution of the cave}

A relevant problem to our discussion is the position of the base level that controlled the main speleogenetic phases of the system. Logically, the base level elevation responsible for the cave formation has been tightly controlled by the sea-level changes, including the poorly known Pliocene sea stands as well as the Quaternary glacioeustatic fluctuations (Dwyer \& Chandler, 2009; Miller et al. 2011). Within this context the temporal evolution of the cave genesis is difficult to establish, owing to the extreme fluctuations in base level elevation mirroring the Mediterranean sea level history (Butzer \& Cuerda, 1962; Zazo, 1999; Ginés et al., 2012); the resulting trend is characterized by a succession of long- 


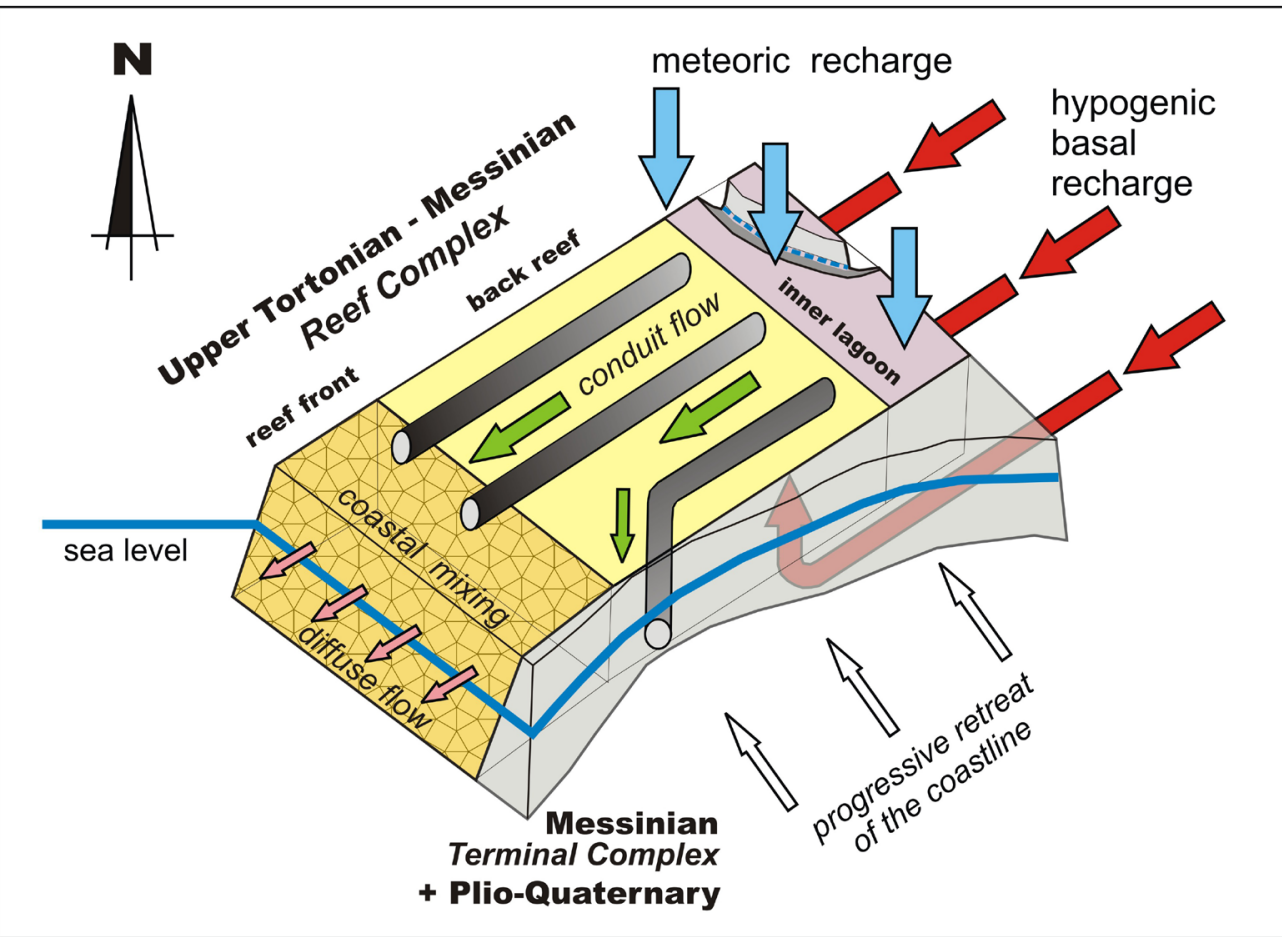

Fig. 15. Hydrogeologic and speleogenetic interpretation of Cova des Pas de Vallgornera. The southward bending of the conduits developed in the back reef seems to be conditioned by the removal of the Messinian and Plio-Quaternary deposits, caused by the progressive retreat of the sea cliffs. At the northern corner of the drawing, the incision of Torrent de Garonda is represented; losses from this creek could have contributed to the meteoric recharge of the aquifer.

lasting regressive events which are intercalated among other events with relatively high sea levels (interglacials and interstadials) sometimes similar or even higher than the current one. Obviously, the formation of Cova des Pas de Vallgornera as a whole must correspond to some high sea stands, which have determined the position of the water table at the moment of the solutional excavation of its main tiers of passages. Difficulties arise when trying to determine a more or less precise chronology for these principal speleogenetic phases.

As previously stated, the inland sectors of the cave system are arranged in two main tiers, disposed respectively close or slightly below the current sea level and between +7 to $+11 \mathrm{~m}$ above it (Fig. 13). There is no solid evidence to establish if these labyrinthine tiers are synchronous in origin and subsequently affected by tectonics or, as opposite, the genesis of the main tiers is diachronic and controlled by Plio-Quaternary sea level fluctuations. Supporting the first possibility, it is necessary to remember that Pliocene and Quaternary shoreline deposits are located along the coastal cliffs of the area at very variable elevations, ranging from close to the sea level to more than $15 \mathrm{~m}$ above. This situation proves the existence of extensional tectonic disturbances, lasting at least from Messinian to the Upper Pleistocene, that are the cause of a progressive lowering of the Plio-Quaternary sequences from the western part of the Llucmajor Platform to the easternmost Campos subsidence basin (Fig. 5). The fact that the two main tiers of passages are well-differentiated, both in elevation and in plan disposition, could suggest the existence of vertical displacements causing the elevation difference observed between the higher Sector Tragus to the north and the lower Sector de Gregal as well as Sector Suabaquàtic de Gregal to the south-east (Figs. 12 and 13).
In a different way -perhaps complementary to the above arguments- there are evidences supporting a diachronic formation of the main maze tiers of the cave system. The planimetric arrangement of the south-eastern sectors (namely Sector de Gregal and Sector Subaquàtic de Gregal) shows a gradual shift from a NW-SE trend to a southerly direction, controlled by the closeness to the coastline (Figs. 8 and 12). Probably this southward bending was favored by the progressive erosion of the Messinian Terminal Complex and the Plio-Quaternary deposits, which outcrop over the erosive surface affecting the Reef Complex carbonates; these deposits probably have acted as an aquitard in the sea direction, until they were almost totally removed by the retreat of the sea cliffs in the small bay near the cave (Fig. 15).

The proposed arguments could support the hypothesis that considers the lower tier of passages (including Sector Subaquàtic de Gregal and Sector de Gregal) to be younger than the upper northern tier (Sector Tragus), because the latter is not affected by the southward trend presumably associated with the Pleistocene sea cliff retreat. Furthermore, the presence of small underwater passages developed below the main galleries of Gran Canyó suggests the extension towards the north of this lower tier of galleries (Fig. 13), so casting doubt on the first possibility consisting in the existence of a unique speleogenetic horizon deformed and compartmented by tectonic movements. Whatever evolutionary hypothesis is considered, the approximate chronology of speleogenesis is difficult to estimate solely on the basis of morphological evidences. Thus, indirect or direct geochronological data on some cave infillings need to be obtained.

\section{Age of speleogenesis}

The chronological key helping to reconstruct the morphogenetic evolution of the cave relies on the paleontological deposit that is located in the northernmost end of Galeria del Tragus (Fig. 7). This huge gallery contains a thick detrital infilling (Fornós et al., 2010b) plentiful of osteological remains of Plio-Quaternary fauna. Endemic species of mammals evolved in an isolated insular environment are well represented, including abundant skeletons and skulls of the Myotragus genus, a bovid which arrived in Mallorca and Menorca in Messinian times (Bover et al., 2008, 2010). The specimens recovered inside the cave correspond to archaic intermediate forms (Fornós et al., 2010b) placed between Myotragus antiquus and Myotragus kopperi, with an age around 2.4-2.6 Ma. These macromammal remains are accompanied by other osteological materials, documented in depth by Bover 
et al. (2014). Several paleontological remains are found in anatomic connection, indicating that some animals entered alive into the cave and without any substantial water or gravity transportation.

The paleontological deposit of Galeria del Tragus is decisive regarding the chronology of Cova des Pas de Vallgornera, because it fixes a terminus ante quem (a minimum age for speleogenesis) for the solutional excavation of the passages. So, it is possible to conclude that at the very beginning of the Pleistocene (about $2.4 \mathrm{Ma}$ ) the galleries of this sector were already formed; their dimensions and general morphology were quite similar to the present-day ones. These data constrain the genesis of the main passages to Pliocene times, falling back at least to some high sea levels that occurred during the mid-Pliocene.

The proposed evolutionary history of the cave is schematically represented in Fig. 16, based upon the

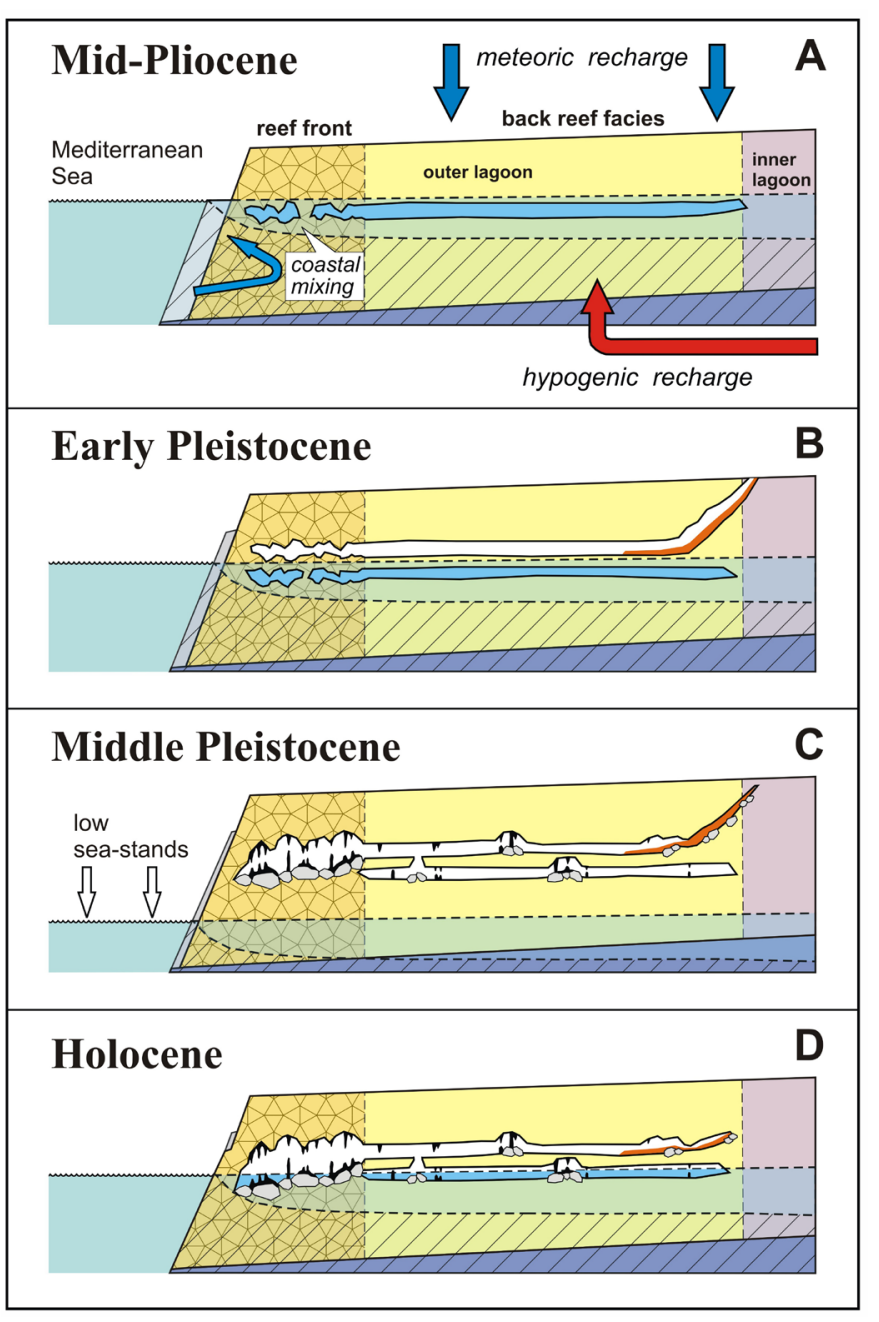

Fig. 16. Evolutionary sequence proposed for Cova des Pas de Vallgornera. A) Excavation of phreatic passages corresponding to some mid-Pliocene high sea stands. The morphology of the passages is lithologically controlled, while the diverse speleogenetic agents involved (not shown in the panels below for simplicity) contribute as well to its morphological variability; B) During a relative low sea level causing the drainage of the upper galleries, the deposition of allochthonous sediments and vertebrate remains takes place through an ancient entrance, today clogged. Phreatic dissolution is probably still active at lower elevations. The paleontological data clearly place this crucial geochronological event in the 2.6-2.4 Ma age range; C) Pleistocene glacioeustatic low stands make possible the formation of vadose speleothems in the nowadays underwater passages, favoring at the same time the actuation of breakdown; D) The post-glacial sea level rise floods with brackish waters the lower passages; overgrowths of aragonite phreatic speleothems are deposited at the current water table. scarce chronological and morphological data that are solid enough. The sequence envisages an important Pliocene speleogenetic phase, with perhaps some additional cave horizons being formed later on during the Upper Pliocene and Lower Pleistocene. Afterwards, in the earliest Pleistocene times, a crucial benchmark is recorded, consisting in the deposition of a thick allochthonous infilling which contains archaic Myotragus remains, whose emplacement is related to the existence of an ancient entrance to the cave system. This ancient access, as some others in which surface Quaternary materials have penetrated (for example in the south eastern end of Sector Grans Sales), is nowadays blocked.

Over the entire Pleistocene, the cave evolution was thoroughly affected by the glacioeustatic fluctuations of sea level, which have favored the development of breakdown phenomena and especially the deposition of vadose speleothems, many of them nowadays drowned by brackish waters. Speleothem formation was intense during the Middle Pleistocene according to the datings supplied by Hodge (2004). Finally, the most recent sea level high stands are well-recorded in the cave as phreatic speleothem overgrowths, corresponding to the Last Interglacial event and to the Holocene rise in sea level (Dorale et al., 2010; Tuccimei et al., 2010).

\section{CONCLUSIONS: A COMPLEX SPELEOGENETIC MODEL}

Explorations in Cova des Pas de Vallgornera stands out as an exceptional discovery within the current knowledge of the karstification in the southern littoral of Mallorca. Its length exceeds $74 \mathrm{~km}$, being the most important cave system in the island and hosting a unique morphological suite among the coastal karst in the Balearic Archipelago.

The cave clearly illustrates the crucial role of lithology as the main factor controlling the pattern and morphologies of its different sectors. Basically, a sharp dichotomy arises between the passages developed in the reef front facies being dominated by spongework features and affected by ubiquitous collapse phenomena, and the back reef galleries that form a maze composed of rather parallel master conduits excavated along important SW-NE fractures. This dichotomy is related to the great differences in porosity and permeability existing both laterally and vertically within the Upper Miocene carbonates, due to the Reef Complex facies architecture.

This cave contains evidence pointing towards a complex speleogenesis that includes, besides coastal mixing dissolution, a noticeable meteoric diffuse recharge and, furthermore, a hypogenic basal input associated with the geothermal phenomena documented in the nearby area.

The principal speleogenetic phases extend back at least to some high sea-stand that occurred in midPliocene times, on the basis of the paleontological vertebrate remains recovered from the cave. The disposition of the cave in two main tiers, relatively individualized both in plan and in elevation, is 
probably the result of speleogenetic phases correlated to different Plio-Quaternary high sea-stands. The southward trend of the lower tier seems to be related to the erosional retreat of the coastal cliffs, therefore being younger than the higher passages and mazes. During the whole Pleistocene, the morphological evolution of the cave was fully controlled by the glacioeustatic fluctuations of the Mediterranean Sea, with extensive deposition of speleothems in passages, which are nowadays drowned.

In spite of its coastal character, it is not possible to fit this kind of large and complex cave system within the flank margin cave category; alternatively, Cova des Pas de Vallgornera shares a lot in common with some continental littoral settings, for example the Quintana Roo caves in the Yucatan Peninsula, as documented by Smart et al. (2006). With our current knowledge of coastal karst it seems necessary to reformulate the Carbonate Island Karst Model (CIKM), shifting towards a Carbonate Coast Karst Model that will take into account the examples coming from larger islands and/or continental areas. This enlarged model should incorporate among other variables those controlling the amount of discharge through the coastal drainage system, namely the climate and especially the extension of the catchment area.

\section{ACKNOWLEDGEMENTS}

The authors are grateful to the numerous cavers involved in the exploration and survey of Cova des Pas de Vallgornera, with a special mention to the following colleagues for their contribution during the field work: Bernat Clamor, Toni Croix, Mateu Fiol, Pere Gamundi, Pau Ginés, Andreas Kristofersson, Guillem Mulet and Toni Mulet. Some photographic material has been kindly supplied by Antoni Cirer, Bogdan P. Onac and Miquel A. Perelló. The discussions with colleagues, during different trips to the cave, have largely enriched our knowledge of the system; among them are: Philippe Audra, Yuri Dublyansky, John E. and Joan R. Mylroie, Bogdan P. Onac as well as Arthur N. and Margaret V. Palmer. Crucial geochronological interpretations are based on the vertebrate paleontological data provided by Pere Bover and Josep A. Alcover (IMEDEA). The geologic field work has benefited by the helpful collaboration supplied by Guillem Mas. Bernadi Gelabert and Lluís Gómez-Pujol have contributed with useful discussion on geologic and geomorphologic aspects of the area. These investigations are integrated within the research project CGL2010-18616 of the Spanish Government (MINECO - FEDER). The Federació Balear d'Espeleologia has given logistic and administrative support to the activities inside the cave as well as provided the updated survey data of the cave. The Conselleria d'Agricultura, Medi Ambient $i$ Territori from Govern de les Illes Balears (the regional environmental authority) has authorized and supported the present investigations. The suggestions and language assistance supplied by John E. Mylroie, Philippe Audra and one anonymous reviewer have greatly improved the original text.

\section{REFERENCES}

Audra P., Mocochain L., Bigot J.Y. \& Nobécourt J.C., 2009 - The association between bubble trails and folia: a morphological and sedimentary indicator of hypogenic speleogenesis by degassing, example from Adaouste Cave (Provence, France). International Journal of Speleology, 38 (2): 93-102. http://dx.doi.org/10.5038/1827-806X.38.2.1

Back W., Hanshaw, B.B. \& Van Driel J.N., 1984 - Role of groundwater in shaping the eastern coastline of the Yucatan Peninsula, Mexico. In: LaFleur R.G. (Ed.), Groundwater as a geomorphic agent. Boston: Allen \& Unwin Inc.: 281-293.

Beddows P.A., 2004 - Groundwater hydrology of a coastal conduit carbonate aquifer: Caribbean coast of the Yucatán Península, México. Unpublished Ph.D. Thesis, University of Bristol, 303 p.

Bover P., Quintana J. \& Alcover J.A., 2008 - Three islands, three worlds: paleogeography and evolution of the vertebrate fauna from the Balearic Islands. Quaternary International, 182: 135-144.

http://dx.doi.org/10.1016/j.quaint.2007.06.039

Bover P., Quintana J. \& Alcover J.A., 2010 - A new species of Myotragus Bate, 1909 (Artiodactyla, Caprinae) from the Early Pliocene of Mallorca (Balearic Islands, western Mediterranean). Geological Magazine, 147 (6): 871-885. http://dx.doi.org/10.1017/S0016756810000336

Bover P., Valenzuela A., Guerra C., Rofes J., Alcover J.A., Ginés J., Fornós J.J., Cuenca-Bescós G. \& Merino A., 2014 - The Cova des Pas de Vallgornera (Llucmajor, Mallorca): a singular deposit bearing an exceptional well preserved Early Pleistocene vertebrate fauna. International Journal of Speleology, 43 (2): 175-192. http://dx.doi.org/10.5038/1827-806X.43.2.6

Butzer K.W. \& Cuerda J., 1962 - Coastal stratigraphy of southern Mallorca and its implications for Pleistocene chronology of the Mediterranean Sea. Journal of Geology, 70: 389-416. http://dx.doi.org/10.1086/626833

Cañellas B., Orfila A., Méndez F.J., Menéndez M., Gómez-Pujol L. \& Tintoré J., 2007 - Application of a POT model to estimate the extreme significant wave height levels around the Balearic Sea (Western Mediterranean). Journal of Coastal Research, Special Issue 51: 329-333.

Clemmensen L.B., Fornós J.J., \& Rodríguez-Perea A., 1997 - Morphology and architecture of Late Pleistocene cliff-front dune, Mallorca, western Mediterranean. Terra Nova, 9: 251-254.

http://dx.doi.org/10.1111/j.1365-3121.1997.tb00023.x

Colom G., 1985 - Estratigrafia y paleontologia del Andaluciense y del Plioceno de Mallorca (Baleares). Boletín Geológico y Minero, 96: 235-302.

Darder B., 1930 - Algunos fenómenos cársicos en la isla de Mallorca. Ibérica, 33 (818): 154-156.

Dorale J.A., Onac B.P., Fornós J.J., Ginés J., Ginés A., Tuccimei P. \& Peate D.W., 2010 - Sea-level highstand 81,000 years ago in Mallorca. Science, 327: 860-863. http://dx.doi.org/10.1126/science. 1181725

Dwyer G.S. \& Chandler M.A., 2009 - Mid-Pliocene sea level and continental ice volume based on coupled benthic $\mathrm{Mg} / \mathrm{Ca}$ palaeotemperatures and oxygen isotopes. Philosophical Transactions of the Royal Society A, 367: 157-168. http://dx.doi.org/10.1098/rsta.2008.0222

Esteban M., 1979 - Significance of the Upper Miocene reefs of the Western Mediterranean. Palaeogeography, Palaeoclimatology, Palaeoecology, 29: 169-188.

http://dx.doi.org/10.1016/0031-0182(79)90080-4 
Faura y Sans M., 1926 - Cuevas de Mallorca. XIV Congreso Geológico Internacional, Instituto Geológico de España, Gráficas Reunidas, S.A. Madrid, 78 p.

Florea L.J., Vacher H.L., Donahue B. \& Naar D., 2007 - Quaternary cave levels in peninsular Florida. Quaternary Science Reviews, 26: 1344-1361. http://dx.doi.org/10.1016/j.quascirev.2007.02.011

Fornós J.J. \& Gelabert B., 1995 - Lithology and tectonics of the Majorcan karst. In: Ginés A. \& Ginés J. (Eds.), Karst and caves in Mallorca. Endins, 20 / Monografies de la Societat d'Història Natural de les Balears, 3: 27-43.

Fornós J.J. \& Pomar L., 1984 - Facies, ambientes y secuencias de plataforma carbonatada somera (Formación Calizas de Santanyí) en el Mioceno Terminal de Mallorca (Islas Baleares). In: Obrador A. (Ed.), Sánchez de la Torre: Barcelona. Cuadernos de Geología, 20: 319-338.

Fornós J.J., Pomar L. \& Ramos-Guerrero E., 2002 - Balearic Islands. In: Gibbons W. \& Moreno T. (Eds.), The Geology of Spain. The Geological Society, London, 327-334.

Fornós J.J., Ginés J. \& Gràcia F., 2009 - Present-day sedimentary facies in the coastal karst caves of Mallorca Island (Western Mediterranean). Journal of Cave and Karst Studies, 71 (1): 86-99.

Fornós J.J., Ginés A., Ginés J., Gràcia F., Merino A., Cifre J. \& Hierro F., 2010a - Hypogene speleogenetic evidences in the development of Cova des Pas de Vallgornera (Mallorca Island, Western Mediterranean). In: Andreo B., Carrasco F., Durán J.J. \& LaMoreaux J.W. (Eds.), Advances in research in karst media. Berlin: Springer-Verlag, Environmental Earth Sciences Series: 349-354.

http://dx.doi.org/10.1007/978-3-642-12486-0_54

Fornós J.J., Ginés J., Merino A. \& Bover P., 2010b - El rebliment sedimentari de la galeria del Tragus a la cova des Pas de Vallgornera (Llucmajor, Mallorca). Bolletí de la Societat d'Història Natural de les Balears, 53: 179-191.

Fornós J.J., Merino A., Ginés J., Ginés A. \& Gràcia F., 2011 - Solutional features and cave deposits related to hypogene speleogenetic processes in a littoral cave of Mallorca Island (western Mediterranean). Carbonates and Evaporites, 26 (1): 69-81.

http://dx.doi.org/10.1007/s13146-010-0040-3

Fornós J.J., Ginés J., Gràcia F., Merino A., Gómez-Pujol L. \& Bover P., 2014 - Cave deposits and sedimentary processes in Cova des Pas de Vallgornera (Mallorca, Western Mediterranean). International Journal of Speleology, 43 (2): 159-174. http://dx.doi.org/10.5038/1827-806X.43.2.5

Gelabert B., 1998 - La estructura geológica de la mitad occidental de la isla de Mallorca. Memorias del Instituto Tecnológico Geominero de España, Madrid, 129 p.

Gelabert B., Sàbat F. \& Rodríguez-Perea, A., 1992 - A structural outline of the Serra de Tramuntana of Mallorca (Balearic Islands). Tectonophysics, 203: 167-183. http://dx.doi.org/10.1016/0040-1951(92)90222-R

Ginés A. \& Ginés J., 1977 - Datos bioespeleológicos obtenidos en las aguas cársticas de la isla de Mallorca. 6è Simposium d'Espeleologia. Escola Catalana d'Espeleologia - S.I.S. del C.E. de Terrassa, 81-95.

Ginés A. \& Ginés J., 1992 - Las Coves del Drac (Manacor, Mallorca). Apuntes históricos y espeleogenéticos. Endins, 17-18: 5-20.

Ginés A. \& Ginés J., 2007 - Eogenetic karst, glacioeustatic cave pools and anchialine environments on Mallorca Island: a discussion of coastal speleogenesis. International Journal of Speleology, 36 (2): 57-67. http://dx.doi.org/10.5038/1827-806X.36.2.1
Ginés A., Ginés J., Gómez-Pujol L., Onac B.P. \& Fornós J.J. (Eds.), 2012 - Mallorca: a Mediterranean benchmark for Quaternary studies. Monografies de la Societat d'Història Natural de les Balears, 18. Palma de Mallorca, 219 p.

Ginés A., Ginés J. \& Gràcia F., 2013 - Cave development and patterns of caves and cave systems in the eogenetic coastal karst of southern Mallorca (Balearic Islands, Spain). In: Lace M.J. \& Mylroie J.E. (Eds.), Coastal karst landforms. Coastal Research Library 5, Springer, Dordrecht, 245-260.

http://dx.doi.org/10.1007/978-94-007-5016-6_11

Ginés J. \& Ginés A., 2006 - La Cova Nova de Son Lluis (Porreres, Mallorca). Notes sobre aspectes històrics $i$ geoespeleològics. Endins, 29: 5-24.

Ginés J. \& Ginés A., 2011 - Classificació morfogenètica de les cavitats càrstiques de les Illes Balears. In: Gràcia F., Ginés J., Pons G.X., Ginard A. \& Vicens D. (Eds.), El carst: patrimoni natural de les Illes Balears. Endins, 35 / Monografies de la Societat d'Història Natural de les Balears, 17: 85-102.

Ginés J., Ginés A., Fornós J.J., Gràcia F. \& Merino A., 2008 - Noves observacions sobre l'espeleogènesi en el Migjorn de Mallorca: els condicionants litològics en alguns grans sistemes subterranis litorals. Endins, 32: 49-79.

Ginés J., Ginés A., Fornós J.J., Merino A. \& Gràcia F., 2009a - About the genesis of an exceptional coastal cave from Mallorca Island (Western Mediterranean). The lithological control over the pattern and morphology of Cova des Pas de Vallgornera. In: White W.B. (Ed.), Proceedings of the $15^{\text {th }}$ International Congress of Speleology, 1. Kerrville, TX: 481-487.

Ginés J., Ginés A., Fornós J.J., Merino A. \& Gràcia $\mathrm{F}$., 2009b - On the role of hypogene speleogenesis in shaping the coastal endokarst of southern Mallorca (Western Mediterranean). In: Klimchouk A.B. \& Ford D.C. (Eds.), Hypogene speleogenesis and karst hydrogeology of artesian basins. Ukrainian Institute of Speleology and Karstology, Simferopol, Special Paper 1: 91-99.

Gómez-Pujol L., Orfila A., Cañellas B., Álvarez-Ellacuría A., Méndez F.J., Medina R. \& Tintoré J., 2007 Morphodynamic classification of sandy beaches in low energetic marine environment. Marine Geology, 242: 235-246.

http://dx.doi.org/10.1016/j.margeo.2007.03.008

Gómez-Pujol L., Gelabert B., Fornós J.J., Pardo-Pascual J.E., Rosselló V.M., Segura F.S. \& Onac B.P., 2013 - Structural control on the presence and character of calas: observations from Balearic Islands limestone rock coast macroforms. Geomorphology, 194: 1-15. http://dx.doi.org/10.1016/j.geomorph.2013.03.012

Gràcia F., Clamor B., Jaume D., Fornós J.J., Uriz M.J., Martín D., Gil J., Gracia P., Febrer M. \& Pons G.X., 2005 - La Cova des Coll (Felanitx, Mallorca): espeleogènesi, geomorfologia, hidrologia, sedimentologia, fauna $i$ conservació. Endins, 27: 141-186.

Gràcia F., Fornós J.J., Gamundí P., Clamor B., Pocoví J. \& Perelló M.A., 2009a - Les descobertes subaquàtiques a la Cova des Pas de Vallgornera (Llucmajor, Mallorca): història $i$ descripció dels descobriments, hidrologia, espeleotemes, sediments, paleontologia i fauna. Endins, 33: $35-72$.

Gràcia F., Fornós J.J., Gamundí P., Clamor B. \& Pocoví J., 2009b - Morfologies de corrosió a la part submergida de la Cova des Pas de Vallgornera. Sector Antic, sector de Gregal i sector de les Grans Sales. Endins, 33: 73-98. 
Gràcia F., Fornós J.J. \& Merino A., 2009c - Corrosion patterns related to meteoric-marine mixing zone in coastal cave systems of Mallorca Island (Western Mediterranean). In: White W.B. (Ed.), Proceedings of the $15^{\text {th }}$ International Congress of Speleology, 1. Kerrville, TX: 496-500.

Gràcia F., Clamor B., Gamundí P. \& Fornós J.J., 2010 El sistema de cavitats Gleda-Camp des Pou (Manacor, Mallorca). Endins, 34: 35-68.

Gràcia F., Clamor B., Gamundí P. \& Fornós J.J., 2011 a Morfologies de corrosió de la zona de mescla a les coves subaquàtiques de la franja litoral del Llevant $i$ Migjorn de Mallorca. In: Gràcia F., Ginés J., Pons G.X., Ginard A. \& Vicens D. (Eds.), El carst: patrimoni natural de les Illes Balears. Endins, 35 / Monografies de la Societat d'Història Natural de les Balears, 17: 133-146.

Gràcia F., Clamor B., Gamundí P., Fornós J.J. \& Watkinson P., 2011b - Les cavitats subaquàtiques de la franja litoral de Mallorca. In: Gràcia F., Ginés J., Pons G.X., Ginard A. \& Vicens D. (Eds.), El carst: patrimoni natural de les Illes Balears. Endins, 35 / Monografies de la Societat d'Història Natural de les Balears, 17: 103-132.

Guijarro J.A., 1995 - Bioclimatic aspects of karst in Mallorca. In: Ginés A. \& Ginés J. (Eds.), Karst and caves in Mallorca. Endins, 20 / Monografies de la Societat d'Història Natural de les Balears, 3: 17-25.

Gulley J.D., Martin J.B., Moore P.J. \& Murphy J., 2013 - Formation of phreatic caves in an eogenetic karst aquifer by $\mathrm{CO} 2$ enrichment at lower water tables and subsequent flooding by sea level rise. Earth Surface Processes and Landforms, 38 (11): 1210-1224. http://dx.doi.org/10.1002/esp.3358

Hodge E.J., 2004 - Palaeoclimate of the Western Mediterranean region: results from speleothems. Unpublished Ph.D. Thesis, University of Bristol. 246 p.

IGME, 1984 - Proyecto de investigación geotérmica preliminar del Pirineo Oriental, zona meridional del prelitoral catalán e Islas Baleares. Vol. 3. Estudio geotérmico preliminar de Baleares. Instituto Geológico y Minero de España, Madrid, 182 p.

Jennings J.N., 1985 - Karst geomorphology. Basil Blackwell, Oxford, 293 p.

Jenson J.W., Keel T.M., Mylroie J.R., Mylroie J.E., Stafford K.W., Taborosi D. \& Wexel C., 2006 - Karst of the Mariana Islands: the interaction of tectonics, glacio-eustasy, and freshwater/seawater mixing in island carbonates. In: Harmon R.S. \& Wicks C. (Eds.), Perspectives on karst geomorphology, hydrology and geochemistry. Geological Society of America, Special Paper 404: 129-138.

Kambesis P.N. \& Coke IV J.G., 2013 - Overview of the controls on eogenetic cave and karst development in Quintana Roo, Mexico. In: Lace M.J. \& Mylroie J.E. (Eds.), Coastal karst landforms. Coastal Research Library 5, Springer, Dordrecht, 347-373.

http://dx.doi.org/10.1007/978-94-007-5016-6_16

Klimchouk A.B., 2007 - Hypogene speleogenesis: hydrogeological and morphogenetic perspectives. National Cave and Karst Research Institute, Carlsbad, New Mexico, Special Paper 1, 106 p.

Klimchouk A.B., 2009 - Morphogenesis of hypogenic caves. Geomorphology, 106: 100-117.

http://dx.doi.org/10.1016/j.geomorph.2008.09.013

Lace M.J. \& Mylroie J.E. (Eds.), 2013 - Coastal karst landforms. Coastal Research Library 5, Springer, Dordrecht, $429 \mathrm{p}$.

http://dx.doi.org/10.1007/978-94-007-5016-6
López J.M., 2007 - Las manifestaciones hidrotermales del sur de Llucmajor, Mallorca. Memòria d'Investigació, Departament de Ciències de la Terra, Universitat de les Illes Balears, Palma. Unpublished. $132 \mathrm{p}$.

López J.M. \& Mateos R.M., 2006 - Control estructural de las anomalias geotérmicas y la intrusión marina en la plataforma de Llucmajor y la cubeta de Campos (Mallorca). Las aguas subterráneas en los países mediterráneos. Instituto Geológico y Minero de España, Madrid. Serie Hidrogeología y Aguas Subterráneas, 17: 607-613.

López J.M., Mateos R.M. \& Ballester A., 2004 Aportaciones del sondeo de investigación geotérmica Lluis Moragues al modelo de funcionamiento hidrogeológico de las aguas termales de la plataforma de Llucmajor (Mallorca). VIII Simposio de Hidrogeología, Zaragoza. 2: 379-388.

Maheu J., 1912 - Exploration et flore souterraine des cavernes de Catalogne et des Iles Baléares. Spelunca, Bulletin et Mémoires de la Société de Spéléologie, 8 (67-68): 1-108.

Martel E.A., 1896 - Sous Terre (neuvième campagne). Cueva del Drach, à Majorque - Scialets du Vercors Chouruns de Dévoluy. Annuaire du Club Alpin Français, 23ème année: 368-413.

Mateos R.M., López J.M. \& Sánchez-Guzmán J., 2005 Most recent explorations projects in Spain. Geothermal research of the Llucmajor area, Mallorca (Balearic Islands). IGA News, 62: 4-7.

Merino A. \& Fornós J.J., 2010 - Los conjuntos morfológicos de flujo ascendente (morphologic suite of rising flow) en la Cova des Pas de Vallgornera (Llucmajor, Mallorca). Endins, 34: 85-100.

Merino A., Fornós J.J. \& Onac B.P., 2009 - Preliminary data on mineralogical aspects of cave rims and vents in Cova des Pas de Vallgornera, Mallorca. In: White W.B. (Ed.), Proceedings of the $15^{\text {th }}$ International Congress of Speleology, 1. Kerrville, TX: 307-311.

Merino A., Ginés J. \& Fornós J.J., 2011a - Evidències morfològiques de processos hipogènics a cavitats de Mallorca. In: Gràcia F., Ginés J., Pons G.X., Ginard A. \& Vicens D. (Eds.), El carst: patrimoni natural de les Illes Balears. Endins, 35 / Monografies de la Societat d'Història Natural de les Balears, 17: 165-182.

Merino A., Mulet A., Mulet G., Croix A., Kristofersson A., Gràcia F., Ginés J., \& Fornós J.J., 2011b - La Cova des Pas de Vallgornera (Llucmajor, Mallorca). La cavitat de major desenvolupament de les Illes Balears. In: Gràcia F., Ginés J., Pons G.X., Ginard A. \& Vicens D. (Eds.), El carst: patrimoni natural de les Illes Balears. Endins, 35 / Monografies de la Societat d'Història Natural de les Balears, 17: 147-164.

Merino A., Mulet A., Mulet G., Croix A., Kristofersson A., Gràcia F. \& Perelló M.A., 2014 - Cova des Pas de Vallgornera (Mallorca, Spain): History of exploration and cave description. International Journal of Speleology, 43 (2): 95-104.

http://dx.doi.org/10.5038/1827-806X.43.2.1

Miller K.G., Mountain G.S., Wright J.D. \& Browning J.V., 2011 - A 180-million-year record of sea level and ice volume variations from continental margin and deepsea isotopic records. Oceanography, 24 (2): 40-53.

Moore P.J., Martin J.B., Screaton E.J. \& Neuhoff P.S., 2010 - Conduit enlargement in an eogenetic karst aquifer. Journal of Hydrology, 393: 143-155.

http://dx.doi.org/10.1016/j.jhydrol.2010.08.008

Mylroie J.E. \& Carew J.L., 1990 - The flank margin model for dissolution cave development in carbonate platforms. Earth Surface Processes and Landforms, 15: 413-424. http://dx.doi.org/10.1002/esp.3290150505 
Mylroie J.E. \& Carew J.L., 2000 - Speleogenesis in coastal and oceanic settings. In: Klimchouk A.B., Ford D.C., Palmer A.N. \& Dreybrodt W. (Eds.), Speleogenesis. Evolution of karst aquifers. Huntsville: National Speleological Society: 226-233.

Mylroie J.E. \& Mylroie J.R., 2009 - Diagnostic features of hypogenic karst: is confined flow necessary. In: Stafford K.W., Land L. \& Veni G. (Eds.), Advances in hypogene karst studies, National Cave and Karst Research Institute Symposium 1. Carlsbad: 12-26.

Mylroie J.R. \& Mylroie J.E., 2007 - Development of the Carbonate Island Karst Model. Journal of Cave and Karst Studies, 69 (1): 59-75.

Nielsen K.A., Clemmensen L.B. \& Fornós, J.J., 2004 - Middle Pleistocene magneto-stratigraphy and susceptibility stratigraphy: Data from carbonate aeolian system, Mallorca, Western Mediterranean. Quaternary Science Reviews, 23: 1733-1756. http://dx.doi.org/10.1016/j.quascirev.2004.02.006

Onac B.P., Fornós J.J., Merino A., Ginés J. \& Diehl J., 2014 - Linking mineral deposits to speleogenetic processes in Cova des Pas de Vallgornera (Mallorca, Spain). International Journal of Speleology, 43 (2): 143157. http://dx.doi.org/10.5038/1827-806X.43.2.4

Palmer A.N., 1991 - Origin and morphology of limestone caves. Geological Society of America Bulletin, 103: 1-21. http://dx.doi.org/10.1130/0016-7606(1991)103 $\leq 0001$ :OAMOLC $>2.3 . \mathrm{CO} ; 2$

Palmer A.N., 2007 - Cave geology. Cave Books, Dayton, Ohio, $454 \mathrm{p}$.

Plummer L.N., 1975 - Mixing of sea water with calcium carbonate ground water. In: Whitten E.H.T. (Ed.), Quantitative studies in geological sciences. Geological Society of America, Memoire 142: 219-236.

Pomar L., 1991 - Reef geometries, erosion surfaces and high-frequency sea-level changes, Upper Miocene Reef Complex, Mallorca, Spain. Sedimentology, 38: 243-269. http://dx.doi.org/10.1111/j.1365-3091.1991.tb01259.x
Pomar L. \& Ward W.C., 1994 - Response of a late Miocene Mediterranean reef platform to high-frequency eustasy. Geology, 22: 131-134. http://dx.doi.org/10.1130/00917613(1994)022<0131:ROALMM>2.3.CO;2

Pomar L., Ward W.C. \& Green D.G., 1996 - Upper Miocene reef complex of the Llucmajor area, Mallorca, Spain. In: Franseen E., Esteban M., Ward W.C. \& Rouchy J.M. (Eds.), Models for carbonate stratigraphy from Miocene reef complexes of the Mediterranean regions. SEPM Concepts in Sedimentology and Paleontology, 5: 191-225.

Sàbat F., Gelabert B., Rodriguez-Perea A. \& Giménez J., 2011 - Geological structure and evolution of Majorca: implications for the origin of the Western Mediterranean. Tectonophysics, 510: 217-238.

http://dx.doi.org/10.1016/j.tecto.2011.07.005

Smart P.L., Beddows P.A., Coke J., Doerr S., Smith S. \& Whitaker F.F., 2006 - Cave development on the Caribbean coast of the Yucatan Peninsula, Quintana Roo, Mexico. In: Harmon R.S. \& Wicks C. (Eds.), Perspectives on karst geomorphology, hydrology and geochemistry. Geological Society of America, Special Paper 404: 105-128.

Thomas C., 2010 - Le karst du Yucatàn: rôle du flux géothermique, des failles, de l'eau de la mer et des évaporites dans sa genèse. Karstologia, 55: 1-18.

Tuccimei P., Soligo M., Ginés J., Ginés A., Fornós J.J.,Kramers J. \& Villa I.M., 2010 - Constraining Holocene sea levels using U-Th ages of phreatic overgrowths on speleothems from coastal caves in Mallorca (Western Mediterranean). Earth Surface Processes and Landforms, 35 (7): 782-790.

Vacher H.L. \& Mylroie J.E., 2002 - Eogenetic karst from the perspective of an equivalent porous medium. Carbonates and Evaporites, 17 (2): 182-196. http://dx.doi.org/10.1007/BF03176484

Zazo C., 1999 - Interglacial sea levels. Quaternary International, 55: 101-113. http://dx.doi.org/10.1016/S1040-6182(98)00031-7 